Pankratz, R. F., S. Hache, P. Sólymos, and E. M. Bayne. 2017. Potential benefits of augmenting road-based breeding bird surveys with autonomous recordings. Avian Conservation and Ecology 12(2):18. https://doi.org/10.5751/ACE-01087-120218

Copyright (C) 2017 by the author(s). Published here under license by the Resilience Alliance.

Methodology, part of a Special Feature on Advancing bird population monitoring with acoustic recording technologies

\title{
Potential benefits of augmenting road-based breeding bird surveys with autonomous recordings
}

\author{
Rhiannon F. Pankratz ${ }^{1}$, Samuel Hache ${ }^{1}$, Péter Sólymos ${ }^{2,3}$ and Erin M. Bayne ${ }^{3}$ \\ ${ }^{1}$ Canadian Wildlife Service, Environment and Climate Change Canada, ${ }^{2}$ Alberta Biodiversity Monitoring Institute, University of \\ Alberta, ${ }^{3}$ Department of Biological Sciences, University of Alberta
}

\begin{abstract}
The North American Breeding Bird Survey (BBS) is one of the longest annual avian surveys and has the greatest spatiotemporally extensive coverage in the Western Hemisphere. Although this important survey provides trend estimates for more than 400 species, it has limited coverage in the boreal forest and biases in representation and detectability that complicate inference. Thus, there is a need to evaluate the potential of new technologies and analytical approaches to increase coverage and improve monitoring efficiency. We documented variation in counts between BBS surveys (hereafter "human BBS") and different on-road and forest-edge surveys using autonomous recording units (ARUs) from 3 routes in the Northwest Territories, Canada. Specifically, we quantified percent differences (i.e., bias in counts) in species richness, abundance indices of birds, and species-specific variation in counts between human BBS and ARU-based surveys conducted on-road and at the forest edge at different dates and times of day. We also generated on-road effective detection radius (EDR) estimates for 15 species and tested for species-specific differences in EDR to explain bias in counts between on-road and forest-edge ARU surveys. Overall, species richness and abundance indices in human BBS surveys were higher than forest-edge ARU surveys conducted simultaneously and when similar forest-edge ARU surveys were conducted at sunset and a week earlier in June. However, there was no difference when comparing values from human BBS with on-road ARU BBS and forest-edge ARU surveys conducted at sunrise. Extracting the maximum count per species from 4 types of 3-minute forest-edge surveys increased counts by $62 \%$ and $64 \%$ for species richness and abundance indices, respectively, relative to human BBS, but the importance of this bias differed considerably among the 10 most common species in the study area. Our results suggest that false-negative bias in species detection could be corrected with appropriate methods, and ARUs deployed at the forest edge near BBS stops could be used to increase data quality of on-road surveys. When combined with appropriate correction factors to adjust for surveys done at the forest edge, ARUs could also be used to increase the geographic coverage of boreal surveys by allowing inexperienced volunteers to collect BBS data along winter or secondary roads in remote locations.
\end{abstract}

\section{Avantages possibles de l'utilisation d'enregistrements autonomes pour accroître le nombre de relevés d'oiseaux nicheurs le long des routes}

RÉSUMÉ. Le Relevé des oiseaux nicheurs d'Amérique du Nord (BBS, pour Breeding Bird Survey en anglais) est un des relevés aviaires annuels les plus anciens; il présente aussi l'étendue spatio-temporelle la plus grande dans l'hémisphère Occidental. Bien que cet important suivi fournisse des estimations de tendance pour plus de 400 espèces, son étendue est limitée en forêt boréale et il comporte des biais sur le plan de la représentation et de la détectabilité qui complique les conclusions. Il appert donc important d'évaluer le potentiel de nouvelles technologies et approches analytiques afin d'accroître la couverture spatiale et l'efficacité de ce suivi. Nous avons étudié les différences de dénombrements entre les relevés BBS (ci-après BBS humains) et divers relevés effectués le long des routes ou à la lisière forestière au moyen d'unités d'enregistrement autonomes (UEA), sur trois routes situées dans les Territoires du Nord-Ouest, Canada. Plus précisément, nous avons quantifié le pourcentage de différence (c.-à-d. les biais de dénombrements) dans le nombre d'espèces, les indices d'abondance des oiseaux et la variation spécifique aux espèces, entre les dénombrements réalisés au moyen de BBS humains ou ceux provenant d'inventaires avec UEA, le long des routes ou à la lisière des forêts, à différentes dates et moments de la journée. Nous avons aussi fait des estimations du rayon de détection effective pour 15 espèces, et avons réalisé des tests pour déterminer les différences de ce rayon spécifiques aux espèces, afin d'expliquer les biais inhérents aux dénombrements par UEA le long des routes et à la lisière des forêts. Dans l'ensemble, le nombre d'espèces et les indices d'abondance provenant des BBS humains étaient supérieurs aux relevés par UEA réalisés simultanément à la lisière forestière, et aussi lorsque ces mêmes relevés par UEA à la lisière forestière étaient effectués au coucher du soleil et une semaine plus tôt en juin. Toutefois, nous n'avons pas observé de différences entre les valeurs obtenues par BBS humains et celles provenant de relevés par UEA installées le long de routes ou à la lisière forestière et réalisés au lever du soleil. L'extraction du dénombrement maximum par espèce à partir de 4 types de relevés de 3 minutes réalisés à la lisière forestière a permis d'augmenter de $62 \%$ et de $64 \%$ le nombre d'espèces et les indices d'abondance, respectivement, par rapport aux BBS humains, mais l'importance de ce biais différait considérablement pour les 10 espèces les plus communes dans l'aire d'étude. Nos résultats indiquent que le biais de faux-négatif dans la détection des espèces pourrait être corrigé au moyen de la méthode appropriée, et que les UEA installées à la lisière forestière près des arrêts de BBS pourraient être utilisées pour accroître la qualité des données des relevés réalisés 
le long des routes. Si elles sont combinées avec les facteurs appropriés pour corriger les relevés effectués à la lisière forestière, les UEA pourraient aussi être utilisées pour augmenter l'étendue spatiale des relevés faits en forêt boréale, puisque des bénévoles inexpérimentés pourraient alors récolter des données de BBS le long de routes d'hiver ou secondaires dans des endroits reculés.

Key Words: autonomous recording units; boreal forest; crepuscular; effective detection radius; forest bird survey; geographic coverage; phenology; singing rate

\section{INTRODUCTION}

The North American Breeding Bird Survey (BBS) is a long-term annual (1966 to present) road-based survey designed to establish population trends for more than 400 bird species (Sauer and Link 2011, Sauer et al. 2013). BBS data have been used in more than 450 scientific publications, for the listing of species at risk, and to inform management and conservation (Downes et al. 2016). However, BBS is limited by poor coverage in northern regions. Only $11 \%$ of BBS surveys done in the boreal forest have been conducted in the northern half of this vast ecosystem (Matsuoka et al. 2011), despite about half of the breeding birds of North America occurring in the boreal forest (Blancher and Wells 2005). As a result, the reliability of trend estimates for most northern species is low (Environment and Climate Change Canada 2016b). The lack of roads in most northern areas and a limited and aging population of volunteers to conduct the BBS have prevented expanded coverage (Farmer et al. 2014). Clearly, there is a need to increase survey coverage in remote boreal regions (Handel and Sauer 2017), but cost-effective approaches will be needed.

A BBS route is a series of 3-minute roadside avian surveys conducted at 50 stops spaced $800 \mathrm{~m}$ apart. Surveys start half an hour before sunrise, and routes are completed within 4-5 hours during the month of June. Point counts conducted during BBS are unlimited in distance, and the area in which birds are detected is generally unknown. The ability of 3-minute avian surveys to provide an accurate representation of the number of breeding individuals and species at a given stop also remains unknown (e.g., Rempel et al. 2014). The mean route-level count of relative abundance generated from BBS is considered appropriate for estimating trends in population size for birds in Canada (Smith et al. 2014). However, there are concerns when BBS data are used to (1) generate population size estimates (e.g., Partners in Flight; Blancher et al. 2013), because roads influence bird behavior (Matsuoka et al. 2011) and sound transmission relative to forest interiors (Haché et al. 2014, Yip, Bayne, et al. 2017), and (2) assess trends for species that are systematically arriving earlier than the June survey period creating declines in population size owing to a change in phenology, but not abundance (Inouye et al. 2000, Parmesan 2007). The BBS in boreal Canada also suffers from a nonrandom distribution of routes, poor habitat representation (Matsuoka et al. 2011), and biased representation of disturbance rates (Betts et al. 2007, Machtans et al. 2014, Van Wilgenburg et al. 2015, Handel and Sauer 2017). The degree to which these add variance to the data and reduce power and precision is a concern. Correcting for some of these biases involves converting counts into density estimates, which requires estimates of detectability and distance sampled. For example, distance sampling can be used to calculate effective detection radius (EDR), which is the radius at which as many birds of a given species are undetected within that distance as are detected beyond that distance (Buckland 2001). Habitat- and species-specific EDR estimates are available for most boreal birds (Matsuoka et al. 2012, Sólymos 2016) but have not been derived for roadside counts in boreal regions. This complicates the integration of on-and off-road data for monitoring birds in forested environments and is required to reduce biases among survey methods (Sólymos et al. 2013).

To effectively increase survey effort in the boreal regions, new technologies, survey designs, and analytical approaches will likely be required to complement efforts from the BBS. Autonomous recording units (ARUs) may provide a solution to augment sparse survey coverage in the boreal forest. ARUs can be programmed to record sounds at predetermined times and over multiple time periods within and among days without the presence of an observer. As a result, ARUs can be deployed in a variety of vegetation types at any time of year, which can increase access in remote regions, e.g., seasonal or winter roads (see Shonfield and Bayne [2017] for an overview of the pros and cons of ARU technology). This new technology can increase data quality and quantity by increasing detection rates of rare species, i.e., irruptive, crepuscular, nocturnal, and less vocal species (Holmes et al. 2014), and facilitate estimation of detection probabilities (e.g., Thompson et al. 2017). Such information should provide a better representation of species composition and abundance indices at each sampling station, as well as reduce the variance in mean number of birds detected for a given species within and among BBS routes and years. Ultimately, this should increase precision of population trend and size estimates. Recording units do not require a skilled observer in the field, so a greater array of volunteers could also be recruited to collect ARU-based data and thereby increase geographic coverage of bird surveys. Although these recordings need to be interpreted by a skilled observer postcollection, automated species recognition algorithms hold promise to aid data interpretation (e.g., Briggs et al. 2012, 2016, Venier et al. 2017).

One complication of potentially using ARUs for BBS sampling is that they cannot be deployed for an extended period of time at the location, i.e., on the road surface, where a standard BBS observer would stand (hereafter "human BBS" and "on-road ARU BBS"). To provide samples along BBS routes, ARUs would need to be placed on a tree at the forest-verge interface (hereafter "forest-edge ARU"). Thus, it is important to assess whether employing ARUs would introduce systematic biases in species richness and speciesspecific abundance indices derived by on-road ARU BBS and forest-edge ARU BBS surveys relative to human BBS surveys, i.e., recordings of the same 3-minute period. Some studies have shown differences in detectability between human- and recording-based surveys, whereas others have not (e.g., Hutto and Stutzman 2009, Campbell and Francis 2011, Venier et al. 2012, Shonfield and Bayne 2017). However, documenting the relative importance of survey type (human vs. ARU-based surveys) and sampling location (on-road vs. forest edge) on bird counts is key to understanding and thereby standardizing differences between human and ARUbased roadside monitoring. 
We examined potential biases in bird counts among human BBS, on-road ARU BBS, and forest-edge ARU BBS counts from three routes in the Northwest Territories, Canada. Specifically, our objective was to quantify the magnitude of differences in species richness, total abundance of birds, and species-specific variation in counts between human BBS and these two ARU survey types, i.e., on-road and forest edge. We also tested for effects of date and time of day using additional forest-edge ARU surveys. We predicted that more species and individual birds would be counted by ARU-based surveys than human-based surveys given that observers can review recordings multiple times and use spectrograms and other aids for data interpretation (Campbell and Francis 2011, Venier et al. 2012). However, we predicted onroad human BBS surveys would count more species and total number of birds than forest-edge ARU BBS surveys because sound transmission paths are more open along roads (Yip, Bayne, et al. 2017). We also estimated EDRs for birds counted by human observers along the three BBS routes. By using EDR as a proxy for probability of detection, we predicted that species-specific differences in counts between on-road ARU BBS versus forestedge ARU BBS surveys would be negatively correlated with estimated EDRs. In other words, species with higher frequency songs (i.e., songs with higher kilohertz would travel shorter distances) would be less likely to be counted by both on-road and forest-edge ARUs for a given BBS stop than those with lower frequency songs (i.e., lower song frequency would travel longer distances). We also predicted that species richness and total number of birds would decrease consistently over consecutive stops along a BBS route and that 1 week earlier (early June; forestedge ARU 1 week earlier) and standardized times of the day (sunrise and sunset) would provide different information about the bird community than the on-road human BBS. To examine potential ways that ARUs could improve roadside surveys and correct for false absences (Toms et al. 2006), we also included a "maximum count" treatment, where information from all forestedge ARU surveys of a given stop (hereafter "forest-edge ARU maximum count") were used to estimate the total number of species counted and maximum count per species; that is, for each species, only values for the treatment with highest count were used for a given stop. Values from this forest-edge ARU maximum count survey provided a reference point to better understand potential contributions of the 4 forest-edge ARU surveys (i.e., forest-edge ARU BBS, forest-edge ARU sunset, forest-edge ARU sunrise, and forest-edge ARU 1 week earlier) to better describe the bird community at a given stop.

\section{METHODS}

\section{Study area and sampling design}

Our study area was located along Highway 3 between Behchokò and Fort Providence in the Northwest Territories (Fig. 1). Highway 3 is a paved 2-lane highway between 11.9 and $16.4 \mathrm{~m}$ wide, including shoulders (Government of the Northwest Territories 2015) and only has an average of 20 cars per BBS route (i.e., 4 cars per hour). It overlaps the Taiga Plains (Level II Ecoregions), mid- and high boreal (Level III Ecoregions), and Great Slave Plain High Boreal and Great Slave Lowland Midboreal ecoregions (Level IV Ecoregions; Ecosystem Classification Group 2007). The more northerly Great Slave Plain High Boreal consists of rapidly drained soils and is dominated by jack pine (Pinus banksiana) stands with sparse common bearberry (Arctostaphylos uva-ursi) and lichen understories. The Great Slave Lowland Midboreal is dominated by treed, shrubby, and sedge-dominated fens. Upland areas consist of mixed forests of jack pine, trembling aspen (Populus tremuloides), balsam poplar (Populus balsamifera), and Alaska paper birch (Betula neoalaskana).

Fig. 1. Location of the three North American Breeding Bird Survey (BBS) routes (pink) included in our study. BBS national coverage and the location of study area within Canada (black box) are shown in inset map. Study area was within the Taiga Plains ecoregion (Ecoregion Level II; Ecosystem Classification Group, 2007).

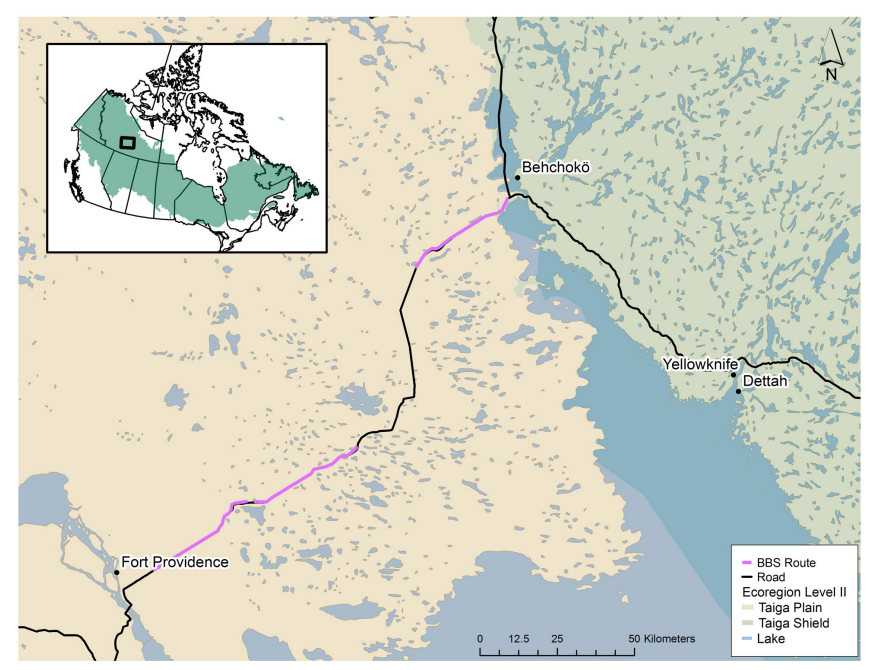

During the last week of May 2015, we deployed an SM3 ARU (Wildlife Acoustics Ltd.) at the forest edge on the western side of the highway, approximately $15-30 \mathrm{~m}$ from each odd-numbered BBS stop (i.e., 25 stops per route, 3 routes). We programmed the ARUs to record from 1 hour before sunset to 4 hours after sunrise continuously every third day throughout June. ARUs had 2 omnidirectional microphones, recorded in stereo, and were programmed to record at a sampling rate of 48,000 Hz. Between 18 and 20 June, 3 BBS routes were surveyed by experienced observers (R. F. Pankratz and S. Hache) following the standard BBS protocol (Sauer et al. 2013). In addition to the standard BBS protocol, surveyors assigned a distance band $(0-50 \mathrm{~m}, 50-100 \mathrm{~m}$, or $>100 \mathrm{~m}$ ) to each individual bird. Observers also used an ARU (Song Meter SM3 from Wildlife Acoustics) mounted on a tripod to record the same 3-minute point counts at the same sampling locations (on-road ARU BBS). For this study, the same 3 minutes of recording from paired on-road ARU BBS and forest-edge ARU BBS surveys were interpreted by 3 skilled observers, i.e., each recording was assigned randomly to an observer. Additional 3minute point counts from forest-edge ARU surveys were also interpreted for each sampling station at the same time as the BBS surveys $\sim 1$ week earlier (11 June), at sunrise the day of the BBS survey (0345-0409), and at sunset the day before the BBS survey (2335-2348). Interpreters used Adobe Audition CS6 (Adobe Systems Inc.) or Song Scope (Wildlife Acoustics Inc.) when 
processing recordings. Recordings that had excessive environmental noise, i.e., many loud events and consistent rain or wind, were removed from analysis if the listener felt that his or her ability to identify birds was compromised.

\section{Statistical analysis}

We used a generalized linear mixed model (GLMM) with a Poisson distribution to compare estimates, direction, and magnitude of differences in species richness and total number of birds between on-road human BBS and other survey types. We first tested for differences in species richness, total number of birds, and species-specific counts ( 10 most common species in the study area) between human BBS and (1) on-road ARU BBS and (2) forest-edge ARU BBS surveys. To account for the hierarchical structure of the sampling design, we added BBS stop nested within BBS route as a random intercept. We used the $\beta$ coefficient for both independent variables (on-road ARU BBS and forest-edge ARU BBS) to generate bias estimates in counts, i.e., percent difference in relative abundance, for each treatment relative to onroad human BBS surveys using the following equation: $100 \times(\exp$ $(\beta)-1)$. The uncertainty of the estimated bias was calculated as the 2.5 and 97.5 percentiles of a similarly transformed distribution based on 1 million random numbers from a normal distribution with $\beta$ mean and squared standard errors from the GLMM as variance. A positive bias suggested that a given survey provided higher counts than on-road human BBS survey, whereas a negative value suggested higher counts from on-road human BBS surveys than a given treatment. Biases were considered significant if $95 \%$ confidence intervals did not overlap zero. A similar modeling framework was used to test for differences in species richness, total number of birds, and species-specific counts between on-road human BBS and (1) forest-edge ARU 1 week earlier, (2) forest-edge ARU sunrise, and (3) forest-edge ARU sunset surveys. An additional model was generated to separately test for differences in species richness, total number of birds, and species-specific counts between on-road human BBS and forestedge ARU maximum count surveys.

We used linear regressions to test for differences in counts (species richness and abundance indices of birds) between on-road ARU BBS and forest-edge ARU sunrise surveys by comparing mean values per stop (3 routes) for both survey types, i.e., tested for within BBS route variation owing to time of day. In this analysis, we included a stop $\times$ survey type interaction as a fixed effect and predicted that differences in counts would be greater with stop number as a result of the linear increase in difference in time of survey between on-road ARU BBS and forest-edge ARU sunrise surveys, i.e., the first BBS stop was conducted half an hour before sunrise and the last one approximately 4 hours after sunrise.

As a proxy for species-specific probability of detection, we estimated human-based on-road EDRs (hereafter "BBS EDRs") using distance for each count estimated during the human BBS surveys. The effective area sampled for a given species can be estimated as $A=\tau^{2} \pi$, $\tau$ being EDR estimated from distance sampling. We assumed that all birds at the observer's location (distance/radius, $d=0$ ) were detected and that radius $r$ is measured without error. Following Sólymos et al. (2013), we estimated EDR using a half-normal detection function $g(r)=\exp \left(-r^{2} / \tau^{2}\right)$, where $\tau^{2}$ is the variance of the unfolded normal distribution. In this model, bird detection declines as distance from the observer increases, but at a slower rate as $\tau$ increases. For species for which we had BBS EDR estimated, we extracted corresponding off-road boreal EDR estimates derived from the Boreal Avian Modelling (BAM) Project database (http://www.borealbirds.ca) using the same analytical approach (Sólymos et al. 2013, Sólymos 2016). BAM uses off-road point count data from across the boreal to generate habitat- and species-specific EDR estimates for 75 species (Sólymos et al. 2013, Barker et al. 2015, Sólymos 2016). BBS EDR estimates were generated for 51 species, but we only report values for those with $\geq 20$ counts during the BBS surveys to assure reliable estimates. We tested the level of correlation between species-specific BBS and BAM EDRs. Given higher detection in open areas (Matsuoka et al. 2012), we predicted that on-road BBS EDRs would be proportionally larger than the offroad BAM EDR estimates. Finally, we used a linear regression to test for an effect of species-specific EDR on bias in counts between on-road ARU BBS and forest-edge ARU BBS surveys. Speciesspecific bias estimates were generated using the same approach used to estimate percent differences between human BBS and ARU-based surveys. Given larger uncertainties in predicted BBS EDRs (Appendix 1), BAM EDR estimates were used in this analysis.

\section{RESULTS}

We processed 351 individual 3-minute recordings from the 5 ARU-based surveys: on-road ARU BBS, forest-edge ARU BBS, forest-edge ARU sunset, forest-edge ARU sunrise, and forestedge ARU 1 week earlier. We counted 3759 vocalizations from 903 unique individuals of 76 species, with the top 10 species being the following: Swainson's Thrush (SWTH; Catharus ustulatus; $\mathrm{n}$ = 375), White-throated Sparrow (WTSP; Zonotrichia albicollis; $\mathrm{n}$ = 368), Hermit Thrush (HETH; Catharus guttatus; $\mathrm{n}=359$ ), Chipping Sparrow (CHSP; Spizella passerina; $\mathrm{n}=328$ ), American Robin (AMRO; Turdus migratorius; $\mathrm{n}=307$ ), Dark-eyed Junco (DEJU; Junco hyemalis; $\mathrm{n}=188$ ), Yellow-rumped Warbler (YRWA; Setophaga coronata; $\mathrm{n}=184$ ), Tennessee Warbler (TEWA; Oreothlypis peregrina; $\mathrm{n}=152$ ), Lincoln's Sparrow (LISP; Melospiza lincolnii; $\mathrm{n}=128$ ), and Lesser Yellowlegs (LEYE; Tringa flavipes; $\mathrm{n}=109$; Appendix 2). Most species (36) were counted less than 10 times ( 8 were counted only once), 23 species were counted between 10 and 60 times, and 13 species were counted more than 60 times.

On-road ARU BBS surveys had similar species richness and abundance to human BBS surveys with only $3.7 \%$ fewer species and $5.7 \%$ more individuals (Fig. 2). Species-specific differences ranged from $23.6 \%$ more (HETH) to $17 \%$ fewer (TEWA) counts for on-road ARU BBS surveys. However, there was large uncertainty around predicted values, and no relationships were considered statistically significant. More important differences were observed when comparing counts from human BBS and forest-edge ARU BBS surveys (Fig. 2). Both species richness and abundance were lower for forest-edge ARU BBS surveys $(8.7 \%$ and $19.3 \%$, respectively), but only the difference in abundance was statistically significantly $(\beta=-0.21$, standard error $[\mathrm{SE}]=0.05$, $z=-4.08, p<0.001)$. Only one species had higher counts during forest-edge ARU BBS surveys (YRWA: 5.6\%), and among the other species with lower counts, the relationship was only statistically significant for $\operatorname{AMRO}(-30.6 \%[\beta=-0.38, \mathrm{SE}=0.18$, $z=-2.16, p<0.031])$. 
Fig. 2. Percent difference ( $95 \%$ confidence interval [CI]) in relative abundance in counts from (1) human North American Breeding Bird Survey (BBS) and on-road autonomous recording unit (ARU) BBS surveys and (2) human BBS and forest-edge ARU BBS surveys. This metric is considered a measure of bias in detection, where values lower than 0 indicate higher counts in human BBS surveys, whereas values higher than 0 indicate higher counts for the other treatment of interest. Darker colors represent statistically significant differences between treatments. See Results for definitions of abbreviations.

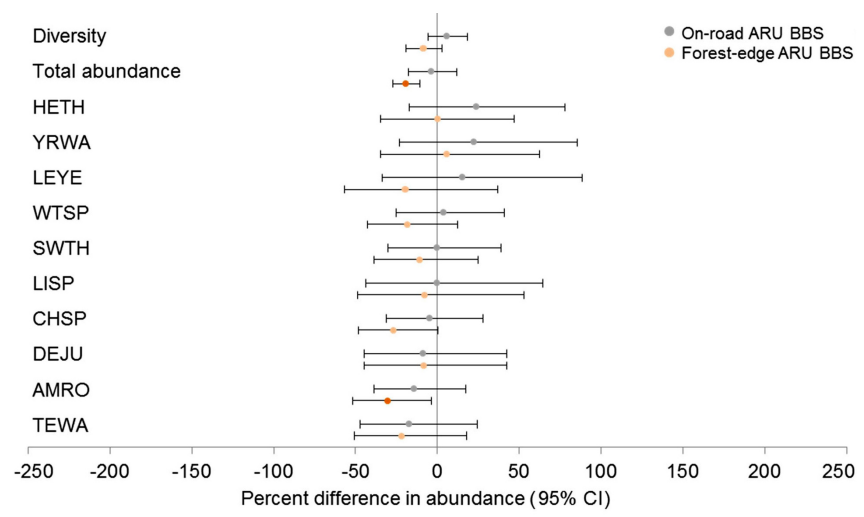

We observed significantly lower species richness and abundance $(-68.3 \%[\beta=-1.10, \mathrm{SE}=0.07, z=-15.61, p<0.001]$ and $-66.0 \%$ $[\beta=-1.15, \mathrm{SE}=0.09, z=13.40, p<0.001]$, respectively; Fig. 3) during forest-edge ARU sunset than human BBS surveys. Only $\operatorname{SWTH}(33.1 \%)$ and HETH $(68.8 \%[\beta=-0.57, \mathrm{SE}=0.18, z=2.8$, $p<0.006])$ had higher counts during sunset surveys, but the relationship was not statistically significant for SWTH. All other species had significantly lower counts during forest-edge ARU sunset surveys (range, $-47.2 \%$ to $-98.0 \% ; p<0.037$ ). Interestingly, a similar pattern was observed when comparing counts between forest-edge ARU 1 week earlier and human surveys, where species richness and abundance were $-26.4 \%(\beta=$ $-0.40, \mathrm{SE}=0.06, z=-7.05, p<0.001)$ and $-32.9 \%(\beta=-0.31$, $\mathrm{SE}=0.07, z=-4.65, p<0.001)$ lower, respectively for the ARU surveys (Fig. 3). Only HETH had higher counts (nonsignificant) during forest-edge ARU surveys 1 week earlier (2.1\%), and TEWA, LEYE, CHSP, and AMRO had counts $>50 \%$ higher during the human BBS surveys $(p<0.023)$. Values for all other species ranged from $-2.9 \%$ to $-29.1 \%$ and were not significantly different. There were small nonsignificant differences in species richness and abundance between forest-edge ARU sunrise and human BBS surveys, where counts were only $9.4 \%$ and $9.2 \%$ lower, respectively, in the former treatment (Fig. 3). Two species had considerably higher counts during forest-edge ARU sunrise surveys (DEJU, 64.8\% [ $\beta=0.48, \mathrm{SE}=0.21, z=2.26, p<0.024]$, and HETH, $81.7 \%[\beta=0.58, \mathrm{SE}=0.18, z=3.20, p=0.001])$, whereas two others showed the opposite pattern (TEWA, $-48.2 \%$ $[\beta=-0.69, \mathrm{SE}=0.27, z=-2.60, p=0.010]$, and LEYE, $-62.8[\beta$ $=-1.06, \mathrm{SE}=0.38, z=-2.81, p=0.005])$. There was also no effect of stop (proxy of effect of time of day), survey (forest-edge BBS vs. forest-edge ARU sunrise), or stop $\times$ survey type interaction effects on species richness or total number of birds (Appendix 3).
Fig. 3. Percent difference ( $95 \%$ confidence interval [CI]) in relative abundance in counts from (1) human North American Breeding Bird Survey (BBS) and forest-edge autonomous recording unit (ARU) sunset surveys, (2) human BBS and forest-edge ARU sunrise surveys, and (3) human BBS and forest-edge ARU 1 week earlier surveys. See Figure 2 legend for details. See Results for definitions of abbreviations.

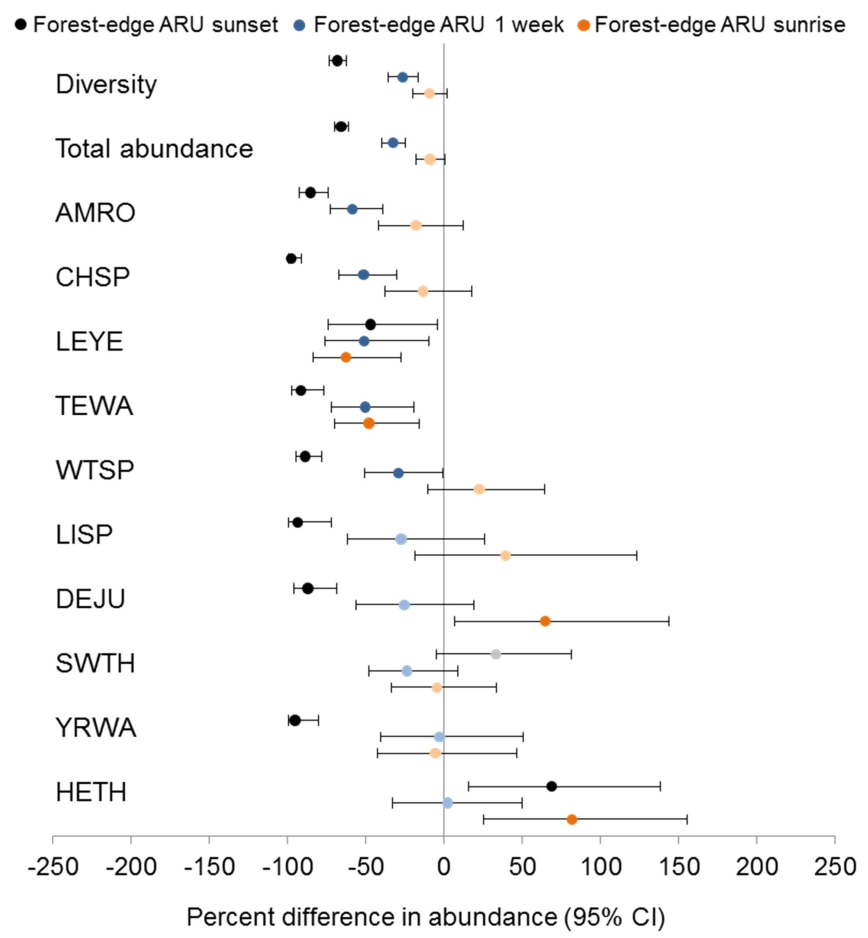

It is interesting to note that other species showed unique treatment responses. Common Nighthawk (CONI; Chordeiles minor) was only counted during the forest-edge ARU sunset treatment (46 individuals counted at 25 stops) with the exception of 1 individual that was observed during a human BBS point count. Ruffed Grouse (RUGR; Bonasa umbellus) was also only counted on ARU recordings (19 individuals, 19 stops). There were considerably higher species richness $(62.0 \%[\beta=0.48, \mathrm{SE}=0.05, z=8.97, p<$ $0.001])$ and abundance $(63.6 \%[\beta=0.49, \mathrm{SE}=0.04, z=11.00, p$ $<0.001]$ ) for the forest-edge ARU maximum count surveys done over multiple days and time periods than human BBS surveys (Fig. 4). Similar patterns were observed for WTSP, SWTH, DEJU, and HETH $(p<0.02)$. There was also an important difference for LISP $(66.6 \%)$, but the difference was not statistically significant. Interestingly, only relatively small nonsignificant differences $(-15.7 \%$ to $22 \%)$ were detected for the other 5 species.

The mean BBS EDR estimate for 15 bird species was $137.4 \mathrm{~m}$ ( \pm 93.4 ) with the lowest value of $68.7 \mathrm{~m}$ for DEJU and highest of $414.1 \mathrm{~m}$ for Wilson's Snipe (Gallinago delicata; Appendix 1). The mean BBS EDR estimate was $60 \%$ higher than the mean BAM EDR estimate, but there was a high correlation among species (Pearson's correlation $r=0.892, p<0.001$ ). Species richness and abundance were $13 \%(\beta=-0.15, \mathrm{SE}=0.06, z=-2.37, p=0.018)$ and $16 \%(\beta=-0.18, \mathrm{SE}=0.05, z=-3.26, p=0.001)$ higher, 
respectively, for on-road ARU BBS versus forest-edge ARU BBS surveys. Effect sizes ranged from only 3\% higher for forest-edge ARU BBS surveys (DEJU) to $28 \%$ higher for on-road ARU BBS surveys (all other species), but these relationships were nonsignificant ( $p>0.12$; Fig. 5). There was a significant negative relationship between BAM EDR and species-specific percent difference in relative abundance between on-road and forest-edge ARU BBS surveys $(t=-2.93, p=0.02)$, but this relationship was not significant if LEYE was removed from the analysis (Appendix 1).

Fig. 4. Percent difference ( $95 \%$ confidence interval $[\mathrm{CI}])$ in relative abundance in counts from human North American Breeding Bird Survey and forest-edge autonomous recording unit maximum count surveys. Black circles indicate statistically significant differences. See Figure 2 legend for details. See Results for definitions of abbreviations.

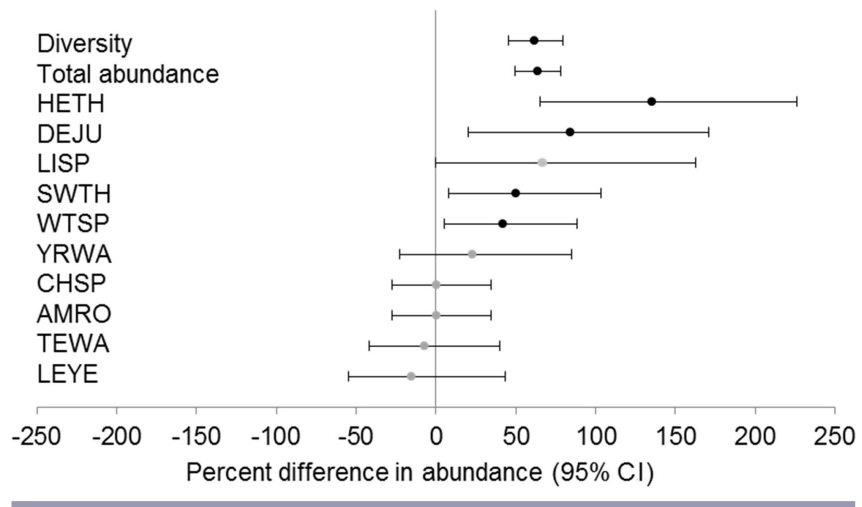

Fig. 5. Percent difference ( $95 \%$ confidence interval $[\mathrm{CI}])$ in relative abundance in counts from on-road autonomous recording unit (ARU) North American Breeding Bird Survey (BBS) and forest-edge ARU BBS surveys. Values lower than 0 indicate higher counts in on-road ARU BBS surveys, whereas values higher than 0 indicate higher counts for the forest-edge ARU BBS survey. Black circles indicate statistically significant differences. See Results for definitions of abbreviations.

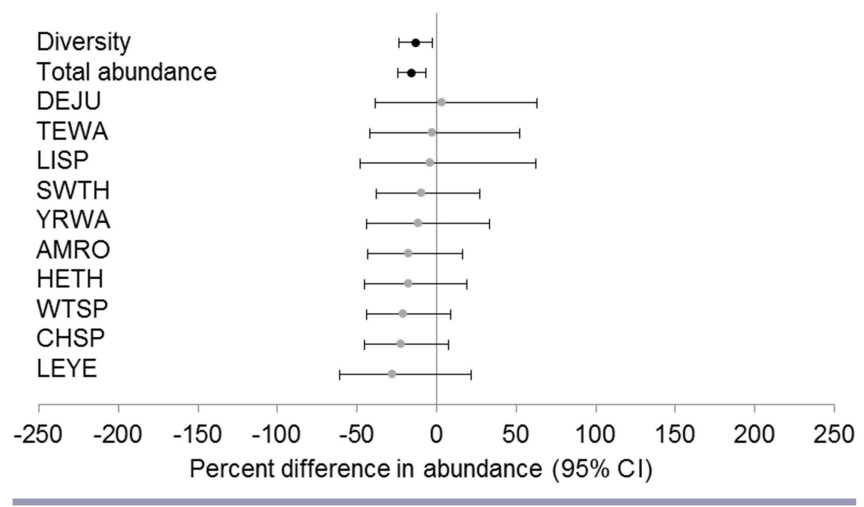

\section{DISCUSSION}

New technology such as ARUs can potentially be used to increase geographic coverage and enhance existing avian monitoring.
However, it is important to quantify differences in counts between human- and ARU-based surveys to ensure that additional biases do not occur when using different techniques or if necessary generate appropriate correction factors. We also need to quantify the extent to which ARUs deployed for longer periods, e.g., forestedge surveys, than traditional human-based avian point count surveys can increase the number of birds and species counted, and how such data can be used effectively. Paired human BBS and on-road ARU BBS surveys showed relatively small (nonsignificant) differences in species richness, total number of birds, and species-specific counts (10 most common species). However, there were significantly lower species richness and total number of birds between on-road ARU BBS and forest-edge ARU BBS surveys, but lower species-specific counts were not significant. Overall, these results indicate that there was limited systematic bias in counts between human and ARU BBS surveys (on-road and forest edge), but correction factors are required to account for some differences, e.g., species-specific biases.

Studies comparing results from human and ARU (Wildlife Acoustic Inc., i.e., Song Meter units) surveys have found both lower ( $8 \%-10 \%$ fewer species with the SM1 unit; Venier et al. 2012, Rempel et al. 2013) and similar ARU performances (SM2 unit; Alquezar and Machado 2015, La and Nudds 2016, but see Klingbeil and Willig 2015, Van Wilgenburg et al. 2017, Yip, Leston, et al. 2017). We used SM3 units and did not observe a significant difference in species richness $(5.7 \%)$ or abundance indices $(-3.7 \%)$ between human BBS and on-road ARU surveys, but nonsignificant species-specific differences ranged from $17.1 \%$ lower to $23.6 \%$ higher in human BBS surveys. The observed differences between human surveys and SM1 units, and human surveys and the SM2 and SM3 units likely reflect the higher signalto-noise ratio in the latter units (e.g., Rempel et al. 2013). However, we found that human BBS surveys greatly undersampled RUGR. Rempel et al. (2013) found that RUGR was missed on ARU recordings, possibly as a result of reduced sensitivity to lowfrequency sounds, but we found that RUGR counts were amplified. This might reflect greater microphone sensitivity in the SM3 relative to previous models. Studies have also reported that human-based surveys can detect species at greater distances than ARU surveys (Venier et al. 2012, Van Wilgenburg et al. 2017, Yip, Leston, et al. 2017). Thus, results from ARU-based surveys are not directly comparable to those from human surveys, and correction factors are needed for the different types of units (i.e., SM2, SM3, etc.) to integrate ARU-based data into larger humanbased point count databases (e.g., Sólymos et al. 2013, Van Wilgenburg et al. 2017, Yip, Leston, et al. 2017).

BBS EDRs were larger than BAM EDRs, which is consistent with increased detection distance from reduced sound attenuation in roadways reported by Yip, Bayne, et al. (2017). We also anticipated that species with smaller BAM EDRs would have a larger bias in counts between on-road ARU BBS and forest-edge ARU BBS surveys, but it was not the case. However, as predicted, both mean predicted species richness and total abundance were higher $(13 \%$ and $16 \%$, respectively) for on-road ARU BBS than forest-edge ARU BBS surveys, and species-specific biases (nonsignificant) ranged from $3 \%$ lower to $28 \%$ higher than on-road BBS. This suggests that additional correction factors would be required to account for bias in counts between these survey types. The BBS EDR estimates we reported provide interesting first 
approximations, but the sampling area used to generate the BBS EDRs would have had an elliptical shape because of how sound travels down "road corridors." Thus, our BBS EDR estimates violate assumptions of traditional distance sampling, i.e., index of abundance is homogeneous and isotropic sound transmission. This important road effect highlights the need to quantify the implications of elliptical effective sampling areas on estimated EDR values. Until an appropriate distance estimation method can be devised for such elliptical sound transmission, density estimates will remain poor from roadside surveys conducted by ARU or human observers alike.

The activity level of most species is known to peak at sunrise and decline as the morning progresses (Robbins 1981, Thompson et al. 2017). However, we found little evidence for higher counts during forest-edge ARU sunrise (but see DEJU and HETH) than during human BBS surveys. In fact, TEWA and LEYE were more often counted during human BBS surveys than forest-edge ARU sunrise surveys. Our surveys were conducted north of the 60th parallel, where photoperiod is significantly longer than in southern regions and in June twilight extends throughout the night. The extent to which the lack of complete darkness and short "nights" (time between sunset and sunrise) affects singing phenology of birds breeding in northern boreal regions and, ultimately, detectability of traditional avian point count surveys remains largely unknown. However, Thompson et al. (2017) also suggested that the lack of complete darkness during the breeding season in Alaska could explain high detection probabilities for many forest birds during multiple hours before and after sunrise.

Similar to changes in vocalization frequency throughout a day, singing rate may vary across the breeding season (Selmi and Boulinier 2003). There were lower counts in overall species richness and abundance and almost all of the common species during surveys conducted in early June (11 June; forest-edge ARU 1 week earlier) than those from later in June (18-20 June; forestedge ARU BBS). BBS requires surveys to be conducted between 28 May and 7 July, with preference given to early or mid-June, and consistency across years for each route. Our results suggest that more work is required to quantify variation in detectability throughout the monitoring period, which is potentially an important source of bias in detection that might differ along a latitudinal gradient and time, i.e., changes in phenology across years (but see Thompson et al. 2017). For example, strong variation in detection during the BBS sampling period is anticipated in more northern regions because of the shorter breeding seasons (Environment and Climate Change Canada 2016a).

Field observers only have 3 minutes during the breeding season to identify birds breeding at a given BBS stop. This can result in low detectability and misidentifications. Reinterpretation of ARU-based data provides an opportunity to correct errors, verify unknowns, and reduce inter- and intraobserver errors (Rempel et al. 2005, Campbell and Francis 2011, Shonfield and Bayne 2017). Another promising contribution of ARUs to the BBS is the possibility to increase data quantity and quality by sampling at different time periods with no additional added field effort. For example, we found that human BBS surveys counted CONI at only $1 \%$ of stops, whereas the species was counted at more than $30 \%$ of the stops when analyzing 3-minute recordings from sunset surveys. It is known that the BBS methodology currently undersamples CONI, a species at risk in Canada (Committee on the Status of Endangered Wildlife in Canada 2007). The use of ARUs to augment BBS coverage could improve our ability to monitor more species and higher abundances by scheduling additional recordings for the sunset period (e.g., SWTH and CONI).

When examining the maximum count across our 4 temporally repeated forest-edge ARU surveys, we found higher species richness and total abundance than traditional BBS surveys. This was achieved by adding only 9 minutes of recordings (total of 12 minutes; 4 forest-edge ARU surveys $\times 3$-minute recordings). Individual forest-edge ARU surveys, though having similar or lower species richness and abundance (e.g., sunset, sunrise, and 1 week earlier) than human BBS surveys, were sampling different species and different abundance indices per species. Assuming that new observations from additional survey time represented birds that were present but unavailable (i.e., did not sing) during the human BBS survey, our results suggest that single 3-minute surveys sample a relatively small portion of the birds breeding at a given BBS stop consistent with Sólymos et al. (2013), but see Thompson et al. (2017). Our results also suggest that ARUs could be effectively used to implement repeat visit survey designs that could correct false absence and detection probabilities for BBS surveys to improve power and precision to identify trends, particularly for rare or hard to detect species. These survey designs may be particularly fruitful given that trend precision is generally low for rare or hard to detect species (Sauer et al. 2013). The low detectability of BBS is particularly problematic when data are being used to generate population size estimates (e.g., Blancher et al. 2013, see also Haché et al. 2014). An optimization analysis is required to determine the optimal number of recordings to transcribe, and it is also important to consider that adding sampling times and dates to BBS surveys is in violation of the closure assumption for most abundance estimators (Farnsworth et al. 2002, Rota et al. 2009). More work will be needed to determine the best modeling framework to address this issue, e.g., occupancy and N-mixture models to quantify superpopulation and account for serially correlated counts (Amundson et al. 2014, Wright et al. 2016).

Despite the potential benefits of using ARUs to increase data quality of BBS and other bird monitoring programs, issues regarding detection biases need to be addressed. For example, there are known differences in counts between recording devices (Venier et al. 2012, Rempel et al. 2013, Alquezar and Machado 2015, Klingbeil and Willig 2015, La and Nudds 2016) and among years for a given microphone (Turgeon et al. 2017). Although this source of variance can be problematic, it is probably similar to observer biases in detection of human-based surveys that have not been as well quantified. Using appropriate field methods (Van Wilgenburg et al. 2017) or using an experimental approach (Yip, Leston, et al. 2017) may remove systematic biases in detection associated with ARU data. Nonetheless, it highlights the importance of monitoring detectability of individual microphones and tracking unit-specific recordings. In addition to this detection bias, ARUbased surveys will always undersample birds that do not vocalize or those in large flocks (e.g., White-winged Crossbill; Loxia leucoptera) where only few individuals vocalize. 
Depending on the protocol, the cost of an ARU-based BBS program would be more than one with volunteer human observers (but see Rempel et al. 2014). For example, a large number of ARUs could be deployed at forest edges to collect data for multiple routes and many days, and an observer with limited bird identification skills could simply record on-road data for each 3-minute BBS stop. The initial start-up cost of purchasing ARUs is considerable, and units will also need to be replaced, but program costs could be reduced considerably if recordings were outsourced to online volunteer crowd-sourcing platforms (e.g., xeno-canto; http:// www.xeno-canto.org/) or processed through the use of automated song recognizers (Briggs et al. 2012, 2016). ARUs might also not need to be deployed annually at the same route or stop to quantify route- and stop-level detection probabilities. However, a detailed cost analysis to evaluate the pros and cons of different ARU-based surveys to enhance BBS is required.

The BBS is one of the most important tools to inform conservation and management of North American bird species, but it currently suffers from a lack of geographic coverage (Machtans et al. 2014, Handel and Sauer 2017), and potential biases (e.g., Matsuoka et al. 2011, Van Wilgenburg et al. 2015) may limit inferences about population trajectories (see also O'Connor et al. 2000). We believe that ARU technology can address some of these limitations and enhance the quality of the BBS and other bird monitoring programs. For example, ARUs could be used to augment BBS survey coverage in the boreal forest and other undersampled areas by establishing dedicated purpose BBS survey routes similar to those created for grassland birds (Dale et al. 2005). However, we need to better understand how data from multiple surveys each year for a given stop could be integrated in the BBS database and trend estimates (e.g., Sólymos et al. 2013, Handel and Sauer 2017). The use of ARU technology offers considerable challenges (reviewed by Shonfield and Bayne 2017), but that should not hinder the collection of data, which could be stored until optimal analytical approaches (data integration) and automated species recognition algorithms (data interpretation) are accessible. This technology should also be considered a way to increase the number of volunteers and geographic coverage of the BBS in northern boreal regions by deploying ARUs at untraditional locations like forest edges along winter and secondary roads or rivers.

Responses to this article can be read online at: http://www.ace-eco.org/issues/responses.php/1087

\section{Acknowledgments:}

We would like to thank Michelle Knaggs, Emily Upham-Mills, Danica Hogan, and Devon Versnick-Brown for their assistance in the field. We are very grateful to Logan McLeod and Emily UphamMills for their help with interpreting recordings and to Michelle Knaggs for her help with resolving unknown vocalizations. We acknowledge contributions from Boreal Avian Modelling (BAM) Project, and thank their team members, avian and biophysical data partners, and funding agencies (including Environment and Climate Change Canada and the U.S. Fish and Wildlife Service). We also want to acknowledge S. L. Van Wilgenburg, Adam C. Smith, and an anonymous reviewer for constructive comments on previous versions of the manuscript. Funding for this research was provided by the Canadian Wildlife Service of Environment and Climate Change Canada.

\section{LITERATURE CITED}

Alquezar, R. D., and R. B. Machado. 2015. Comparisons between autonomous acoustic recordings and avian point counts in open woodland savanna. Wilson Journal of Ornithology 127 (4):712-723. http://dx.doi.org/10.1676/14-104.1

Amundson, C. L., J. A. Royle, and C. M. Handel. 2014. A hierarchical model combining distance sampling and time removal to estimate detection probability during avian point counts. Auk 131(4):476-494. http://dx.doi.org/10.1642/AUK-14-11.1

Barker, N. K. S., P. C. Fontaine, S. G. Cumming, D. Stralberg, A. Westwood, E. M. Bayne, P. Sólymos, F. K. A. Schmiegelow, S. J. Song, and D. J. Rugg. 2015. Ecological monitoring through harmonizing existing data: lessons from the Boreal Avian Modelling Project. Wildlife Society Bulletin 39:480-487. http://dx. doi.org/10.1002/wsb.567

Betts, M. G., D. Mitchell, A. W. Diamond, and J. Bety. 2007. Uneven rates of landscape change as a source of bias in roadside wildlife surveys. Journal of Wildlife Management 71:2266-2273. http://dx.doi.org/10.2193/2006-004

Blancher, P. J., K. V. Rosenberg, A. O. Panjabi, B. Altman, A. R. Couturier, W. E. Thogmartin, and the Partners in Flight Science Committee. 2013. Handbook to the Partners in Flight Population Estimates Database, version 2.0. PIF Technical Series No. 6. Partners in Flight. [online] URL: http://pif.birdconservancy.org/ PopEstimates/downloads/Handbook $\% 20$ to $\% 20$ the $\% 20$ PIF $\%$ 20Population $\%$ 20Estimates $\% 20$ Database $\% 20$ Version $\% 202.0$.pdf

Blancher, P., and J. Wells. 2005. The boreal forest region: North America's bird nursery. Canadian Boreal Initiative, Ottawa, Ontario, Canada; Boreal Songbird Initiative, Seattle, Washington, USA.

Briggs, F., X. Z. Fern, R. Raich, and M. Betts. 2016. Multiinstance multi-label class discovery: a computation approach for assessing bird biodiversity. Pages 3807-3813 in Proceedings of the Thirtieth Association for the Advancement of Artificial Intelligence Conference on Artificial Intelligence (AAAI-16) (Phoenix, Arizona, USA; 12-17 February 2016). AAAI Press, Palo Alto, California, USA.

Briggs, F., B. Lakshminarayanan, L. Neal, X. Z. Fern, R. Raich, S. J. K. Hadley, A. S. Hadley, and M. G. Betts. 2012. Acoustic classification of multiple simultaneous bird species: a multiinstance multi-label approach. Journal of the Acoustical Society of America 131(6):4640-4650. http://dx.doi.org/10.1121/1.4707424

Buckland, S. T. 2001. Introduction to distance sampling: estimating abundance of biological populations. Oxford University Press, New York, New York, USA.

Campbell, M., and C. M. Francis. 2011. Using stereomicrophones to evaluate observer variation in North American Breeding Bird Survey point counts. Auk 128(2):303-312. http:// dx.doi.org/10.1525/auk.2011.10005 
Committee on the Status of Endangered Wildlife in Canada (COSEWIC). 2007. COSEWIC assessment and status report on the Common Nighthawk (Chordeiles minor) in Canada. COSEWIC, Ottawa, Ontario, Canada. [online] URL: https:// www.registrelep-sararegistry.gc.ca/document/default_e.cfm? documentID $=1393$

Dale, B., M. Norton, C. Downes, and B. Collins. 2005. Monitoring as a means to focus research and conservation - the Grassland Bird Monitoring example. Pages 485-495 in C. J. Ralph and T. D. Rich, editors. Bird conservation implementation and integration in the Americas: proceedings of the third international Partners in Flight conference. General Technical Report PSW-GTR-191. U. S. Forest Service, Pacific Southwest Research Station, Albany, California, USA.

Downes, C. M., M.-A. R. Hudson, A. C. Smith, and C. M. Francis. 2016. The Breeding Bird Survey at 50: scientists and birders working together for bird conservation. Avian Conservation and Ecology 11(1):8. http://dx.doi.org/10.5751/ ACE-00855-110108

Ecosystem Classification Group. 2007. Ecological regions of the Northwest Territories: Taiga Plains. Government of the Northwest Territories, Yellowknife, Northwest Territories, Canada.

Environment and Climate Change Canada. 2016a. General nesting periods of migratory birds in Canada. Government of Canada, Ottawa, Ontario, Canada. [online] URL: https://www. canada.ca/en/environment-climate-change/services/avoiding-harmmigratory-birds/general-nesting-periods.html

Environment and Climate Change Canada. 2016b. North American Breeding Bird Survey: national coverage. Government of Canada, Ottawa, Ontario, Canada. [online] URL: https:// www.canada.ca/en/environment-climate-change/services/bird-surveys/ landbird/north-american-breeding.html

Farmer, R. G., M. L. Leonard, J. E. Mills Flemming, and S. C. Anderson. 2014. Observer aging and long-term avian survey data quality. Ecology and Evolution 4(12):2563-2576. http://dx.doi. org/10.1002/ece3.1101

Farnsworth, G. L., K. H. Pollock, J. D. Nichols, T. R. Simons, J. E. Hines, and J. R. Sauer 2002. A removal model for estimating detection probabilities from point-count surveys. Auk 119:414-425. http://dx.doi.org/10.1642/0004-8038(2002)119[0414: ARMFED]2.0.CO;2

Government of the Northwest Territories. 2015. Northwest Territories transportation report card. Tabled Document 345-17 (5). Government of the Northwest Territories, Yellowknife, Northwest Territories, Canada.

Haché, S., P. Sólymos, T. Fontaine, E. M. Bayne, S. Cumming, F. Schmiegelow, and D. Stralberg. 2014. Analyses to support critical habitat identification for Canada Warbler, Olive-sided Flycatcher, and Common Nighthawk (Project K4B20-13-0367). Technical Report for Environment Canada. Boreal Avian Modelling Project, Edmonton, Alberta, Canada.

Handel, C. M., and J. R. Sauer. 2017. Combined analysis of roadside and off-road breeding bird survey data to assess population change in Alaska. Condor 119:557-575. http://dx.doi. org/10.1650/CONDOR-17-67.1
Holmes, S. B., K. A. McIlwrick, and L. A. Venier. 2014. Using automated sound recording and analysis to detect bird speciesat-risk in southwestern Ontario woodlands. Wildlife Society Bulletin 38:591-598. http://dx.doi.org/10.1002/wsb.421

Hutto, R. L., and R. J. Stutzman. 2009. Humans versus autonomous recording units: a comparison of point-count results. Journal of Field Ornithology 80(4):387-398. http://dx.doi. org/10.1111/j.1557-9263.2009.00245.x

Inouye, D. W., B. Barr, K. B. Armitage, and B. D. Inouye. 2000. Climate change is affecting altitudinal migrants and hibernating species. Proceedings of the National Academy of Sciences of the United States of America 97:1630-1633. http://dx.doi. org/10.1073/pnas.97.4.1630

Klingbeil, B. T., and M. R. Willig. 2015. Bird biodiversity assessments in temperate forest: the value of point count versus acoustic monitoring protocols. PeerJ 3:e973. http://dx.doi. org/10.7717/peerj.973

La, V. T., and T. D. Nudds. 2016. Estimation of avian species richness: biases in morning surveys and efficient sampling from acoustic recordings. Ecosphere 7(4):e01294. http://dx.doi. org/10.1002/ecs2.1294

Machtans, C. S., K. J. Kardynal, and P. A. Smith. 2014. How well do regional or national Breeding Bird Survey data predict songbird population trends at an intact boreal site? Avian Conservation and Ecology 9(1):5. http://dx.doi.org/10.5751/ ACE-00649-090105

Matsuoka, S. M., E. M. Bayne, P. Sólymos, P. C. Fontaine, S. G. Cumming, F. K. A. Schmiegelow, and S. J. Song. 2012. Using binomial distance-sampling models to estimate the effective detection radius of point-count surveys across boreal Canada. Auk 129(2):268-282. http://dx.doi.org/10.1525/auk.2012.11190

Matsuoka, S. M., P. Sólymos, T. Fontaine, and E. M. Bayne. 2011. Roadside surveys of boreal forest birds: how representative are they and how can we improve current sampling? Technical Report for Environment Canada. Boreal Avian Modelling Project, Edmonton, Alberta, Canada.

O’Connor, R. J., E. Dunn, D. H. Johnson, S. L. Jones, D. Petit, K. Pollock, C. R. Smith, J. L. Trapp, and E. Welling. 2000. A programmatic review of the North American breeding bird survey: report of a peer review panel. U.S. Geological Survey Patuxent Wildlife Research Center, Laurel, Maryland, USA.

Parmesan, C. 2007. Influences of species, latitudes and methodologies on estimates of phenological response to global warming. Global Change Biology 13:1860-1872. http://dx.doi. org/10.1111/j.1365-2486.2007.01404.X

Rempel, R. S., C. M. Francis, J. N. Robinson, and M. Campbell. 2013. Comparison of audio recording system performance for detecting and monitoring songbirds. Journal of Field Ornithology 84(1):86-97. http://dx.doi.org/10.1111/jofo. 12008

Rempel, R. S., K. A. Hobson, G. Holborn, S. L. Van Wilgenburg, and J. Elliott. 2005. Bioacoustic monitoring of forest songbirds: interpreter variability and effects on configuration and digital processing methods in the laboratory. Journal of Field Ornithology 76(1):1-11. http://dx.doi.org/10.1648/0273-8570-76.1.1 
Rempel, R. S., J. M. Jackson, and J. N. Robinson. 2014. Acoustic monitoring and assessment of forest songbirds: sample design, analysis methods, and observation error. CNFER Technical Report TR-012. Ontario Ministry of Natural Resources, Centre for Northern Forest Ecosystem Research, Thunder Bay, Ontario, Canada.

Robbins, C. S. 1981. Effect of time of day on bird activity. Pages 275-286 in J. C. Ralph and M. J. Scott, editors. Studies in avian biology. Allen, Lawrence, Kansas, USA.

Rota, C. T., R. J. Fletcher, Jr., R. M. Dorazio, and M. G. Betts. 2009. Occupancy estimation and the closure assumption. Journal of Applied Ecology 46:1173-1181. http://dx.doi.org/10.1111/ j.1365-2664.2009.01734.x

Sauer, J. R., and W. A. Link. 2011. Analysis of the North American Breeding Bird Survey using hierarchical models. Auk 128(1):87-98. http://dx.doi.org/10.1525/auk.2010.09220

Sauer, J. R., W. A. Link, J. E. Fallon, K. L. Pardieck, and D. J. Ziolkowski, Jr. 2013. The North American Breeding Bird Survey 1966-2011: summary analysis and species accounts. North American Fauna 79:1-32. http://dx.doi.org/10.3996/nafa.79.0001

Selmi, S., and T. Boulinier. 2003. Does time of season influence bird species number determined from point-count data? A capture-recapture approach. Journal of Field Ornithology 74:349-356. http://dx.doi.org/10.1648/0273-8570-74.4.349

Shonfield, J., and E. M. Bayne. 2017. Autonomous recording units in avian ecological research: current use and future applications. Avian Conservation and Ecology 12(1):14. http://dx.doi. org/10.5751/ACE-00974-120114

Smith, A. C., M-.A. R. Hudson, C. Downes, and C. M. Francis. 2014. Estimating breeding bird survey trends and annual indices for Canada: how do the new hierarchical Bayesian estimates differ from previous estimates? Canadian Field-Naturalist 128 (2):119-134. http://dx.doi.org/10.22621/cfn.v128i2.1565

Sólymos, P. 2016. QPAD version 3 documentation. Technical Report. Boreal Avian Modelling Project, Edmonton, Alberta, Canada.

Sólymos, P., S. M. Matsuoka, E. M. Bayne, S. R. Lele, P. Fontaine, S. G. Cumming, D. Stralberg, F. K. A. Schmiegelow, and S. J. Song. 2013. Calibrating indices of avian density from nonstandardized survey data: making the most of a messy situation. Methods in Ecology and Evolution 4:1047-1058. http://dx.doi. org/10.1111/2041-210X.12106

Thompson, S. J., C. M. Handel, and L. B. McNew. 2017. Autonomous acoustic recorders reveal complex patterns in avian detection probability. Journal of Wildlife Management 81:1228-1241. http://dx.doi.org/10.1002/jwmg.21285
Toms, J. D., F. K. A. Schmiegelow, S. J. Hannon, and M.-A. Villard. 2006. Are point counts of boreal songbirds reliable proxies for more intensive abundance estimators? Auk 123:438-454.

Turgeon, P. J., S. L. Van Wilgenburg, and K. L. Drake. 2017. Microphone variability and degradation: implications for monitoring programs employing autonomous recording units. Avian Conservation and Ecology 12(1):9. http://dx.doi. org/10.5751/ACE-00958-120109

Van Wilgenburg, S. L., E. M. Beck, B. Obermayer, T. Joyce, and B. Weddle. 2015. Biased representation of disturbance rates in the roadside sampling frame in boreal forests: implications for monitoring design. Avian Conservation and Ecology 10(2):5. http://dx.doi.org/10.5751/ACE-00777-100205

Van Wilgenburg, S. L., P. Sólymos, K. J. Kardynal, and M. D. Frey. 2017. Paired sampling standardizes point count data from humans and acoustic recorders. Avian Conservation and Ecology 12(1):13. http://dx.doi.org/10.5751/ACE-00975-120113

Venier, L. A., S. B. Holmes, G. W. Holborn, K. A. McIlwrick, and G. Brown. 2012. Evaluation of an automated recording device for monitoring forest birds. Wildlife Society Bulletin 36(1):30-39. http://dx.doi.org/10.1002/wsb.88

Venier, L. A., M. J. Mazerolle, A. Rodgers, K. A. McIlwrick, S. Holmes, and D. Thompson. 2017. Comparison of semiautomated bird song recognition with manual detection of recorded bird song samples. Avian Conservation and Ecology 12(2):2. http://dx. doi.org/10.5751/ACE-01029-120202

Wright, W. J., K. M. Irvine, and T. J. Rodhouse. 2016. A goodnessof-fit test for occupancy models with correlated within-season revisits. Ecology and Evolution 6(15):5404-5415. http://dx.doi. org/10.1002/ece3.2292

Yip, D. A., E. M. Bayne, P. Sólymos, J. Campbell, and D. Proppe. 2017. Sound attenuation in forest and roadside environments: implications for avian point-count surveys. Condor 119:73-84. http://dx.doi.org/10.1650/CONDOR-16-93.1

Yip, D. A., L. Leston, E. M. Bayne, P. Sólymos, and A. Grover. 2017. Experimentally derived detection distances from audio recordings and human observers enable integrated analysis of point count data. Avian Conservation and Ecology 12(1):11. http:// dx.doi.org/10.5751/ACE-00997-120111
Editor-in-Chief: Keith A.Hobson Subject Editor: Steven L.Van Wilgenburg
Sponsored by the Society of Canadian Ornithologists and Bird Studies Canada Parrainée par la Société des ornithologistes $d u$ Canada et Etudes d'oiseaux Canada

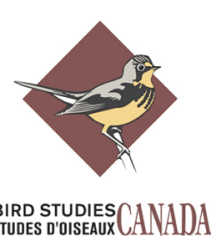


Appendix 1. Effective detection radius (EDR) estimates for the 15 species with $\geq 20$ detections from North American Breeding Bird Survey (BBS) surveys on 3 routes in the Northwest Territories.

Table A1.1. EDR estimates for the 15 species with $\geq 20$ detections from BBS surveys on 3 routes in the Northwest Territories. Estimates generated from the BAM database are presented for comparison. In parentheses are upper and lower $90 \%$ confidence intervals followed by the sample size.

\begin{tabular}{|c|c|c|}
\hline Species & BAM EDR (m) & BBS EDR (m) \\
\hline \multirow[t]{2}{*}{ Alder Flycatcher (Empidonax alnorum) } & 82.01 & 120.43 \\
\hline & $(81.35-82.67 ; 10,286)$ & $(99.88-143.43 ; 27)$ \\
\hline \multirow[t]{2}{*}{ American Robin (Turdus migratorius) } & 93.72 & 97.06 \\
\hline & $(93.26-94.19 ; 27,663)$ & $(87.89-106.81 ; 66)$ \\
\hline \multirow[t]{2}{*}{ Chipping Sparrow (Spizella passerine) } & 70.11 & 87.34 \\
\hline & $(69.72-70.49 ; 23,420)$ & $(80-30-94.77 ; 82)$ \\
\hline \multirow[t]{2}{*}{ Dark-eyed Junco (Junco hyemalis) } & 68.12 & 68.71 \\
\hline & $(67.65-68.60 ; 12,376)$ & $(60.19-77.96 ; 38)$ \\
\hline \multirow[t]{2}{*}{ Hermit Thrush (Catharus guttatus) } & 103.88 & 188.03 \\
\hline & $(103.19-104.58 ; 18,159)$ & $(156.11-223.82 ; 50)$ \\
\hline \multirow[t]{2}{*}{ Lesser Yellowlegs (Tringa flavipes) } & 127.90 & 253.60 \\
\hline & $(123.23-132.68 ; 851)$ & $(171.22-357.22 ; 29)$ \\
\hline \multirow{2}{*}{ Lincoln's Sparrow (Melospiza lincolnii) } & 70.08 & 83.20 \\
\hline & $(69.40-70.77 ; 6,836)$ & $(71.34-96.23 ; 32)$ \\
\hline \multirow[t]{2}{*}{ Orange-crowned Warbler (Oreothlypis celata) } & 63.05 & 73.58 \\
\hline & $(61.94-64.16 ; 2,113)$ & $(62.00-86.46 ; 24)$ \\
\hline \multirow[t]{2}{*}{ Palm Warbler (Setophaga palmarum) } & 60.51 & 77.09 \\
\hline & $(59.60-61.43 ; 2,784)$ & $(67.89-87.04 ; 39)$ \\
\hline \multirow[t]{2}{*}{ Ruby-crowned Kinglet (Regulus calendula) } & 78.32 & 120.66 \\
\hline & $(77.79-78.85 ; 15,003)$ & $(93.87-151.79 ; 20)$ \\
\hline \multirow[t]{2}{*}{ Swainson's Thrush (Catharus ustulatus) } & 83.89 & 166.51 \\
\hline & $(83.51-84.27 ; 30,285)$ & $(144.34-190.76 ; 73)$ \\
\hline \multirow[t]{2}{*}{ Tennessee Warbler (Oreothlypis peregrine) } & 59.54 & 73.80 \\
\hline & $(59.29-59.79 ; 27,681)$ & $(65.90-82.29 ; 39)$ \\
\hline \multirow[t]{2}{*}{ Wilson's Snipe (Gallinago delicate) } & 122.85 & 414.14 \\
\hline & $(120.85-124.86 ; 4,425)$ & $(217.52-696.22 ; 25)$ \\
\hline \multirow[t]{2}{*}{ White-throated Sparrow (Zonotrichia albicollis) } & 92.76 & 162.99 \\
\hline & $(92.44-93.08 ; 50,964)$ & $(141.28-186.69 ; 69)$ \\
\hline \multirow[t]{2}{*}{ Yellow-rumped Warbler (Setophaga coronate) } & 59.11 & 73.56 \\
\hline & $(58.88-59.33 ; 40,720)$ & $(65.26-82.49 ; 43)$ \\
\hline
\end{tabular}




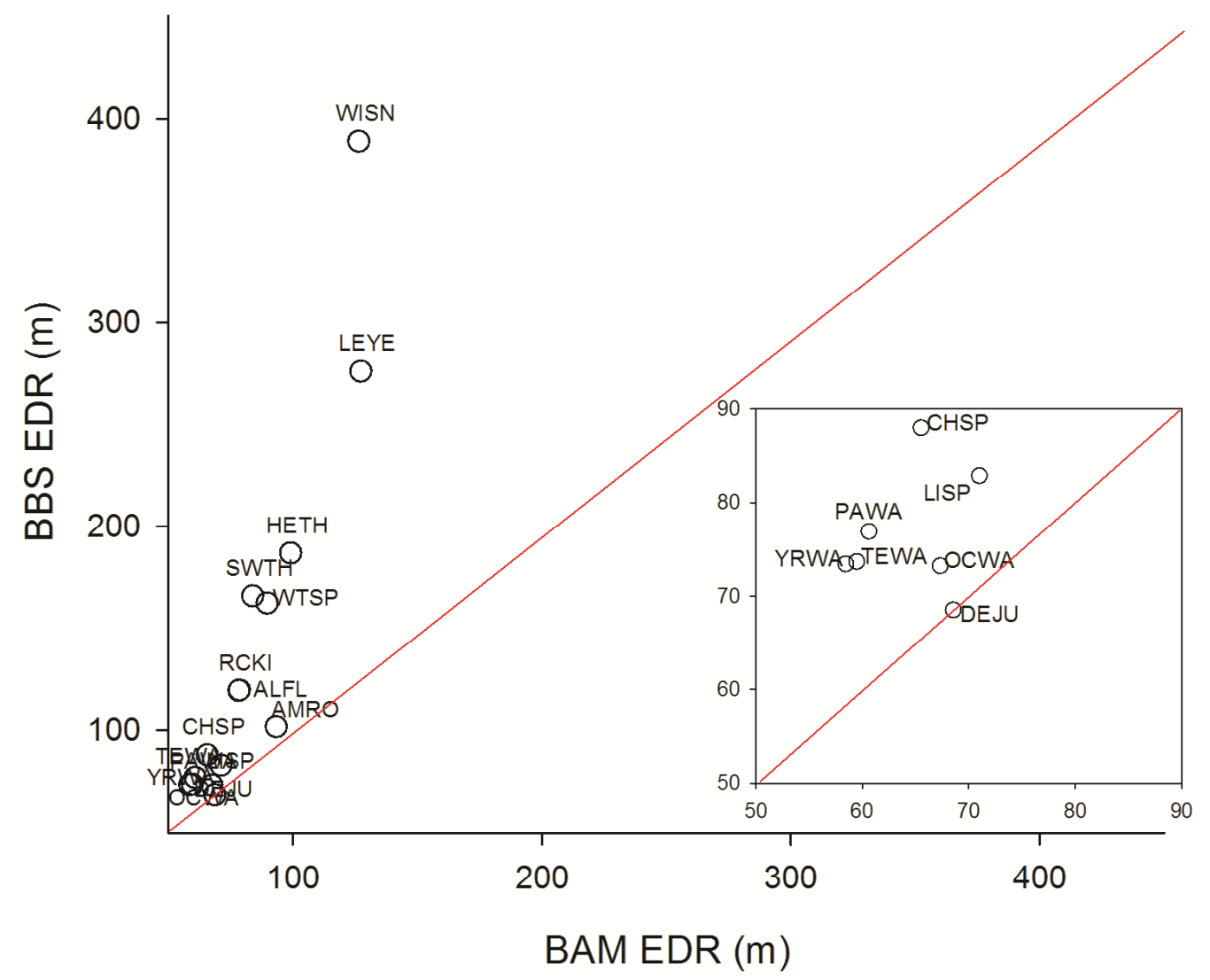

Figure A1.1. Relationship between on-road human BBS and BAM EDR estimates for the 15 forest birds most often detected in this study. Inset graph enlarges clustered area while red line depicts slope of 1. 


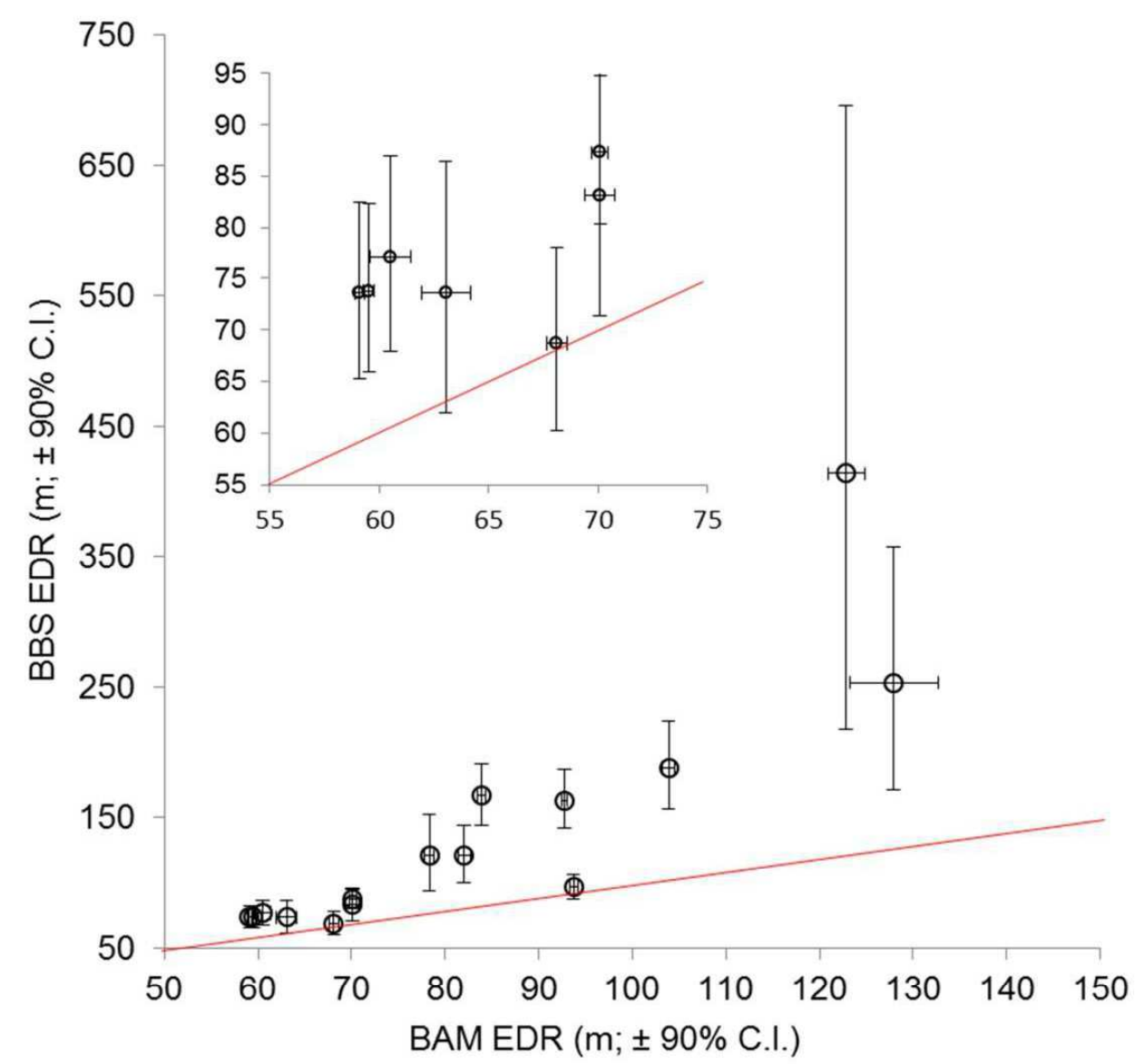

Figure A1.2. Relationship between on-road human BBS and BAM EDR estimates ( $\pm 90 \%$ C.I.) for the 15 forest birds most often detected in this study. Inset graph enlarges clustered area while red line depicts slope of 1 (note that the difference in scales between both axes was to effectively report confidence intervals). 


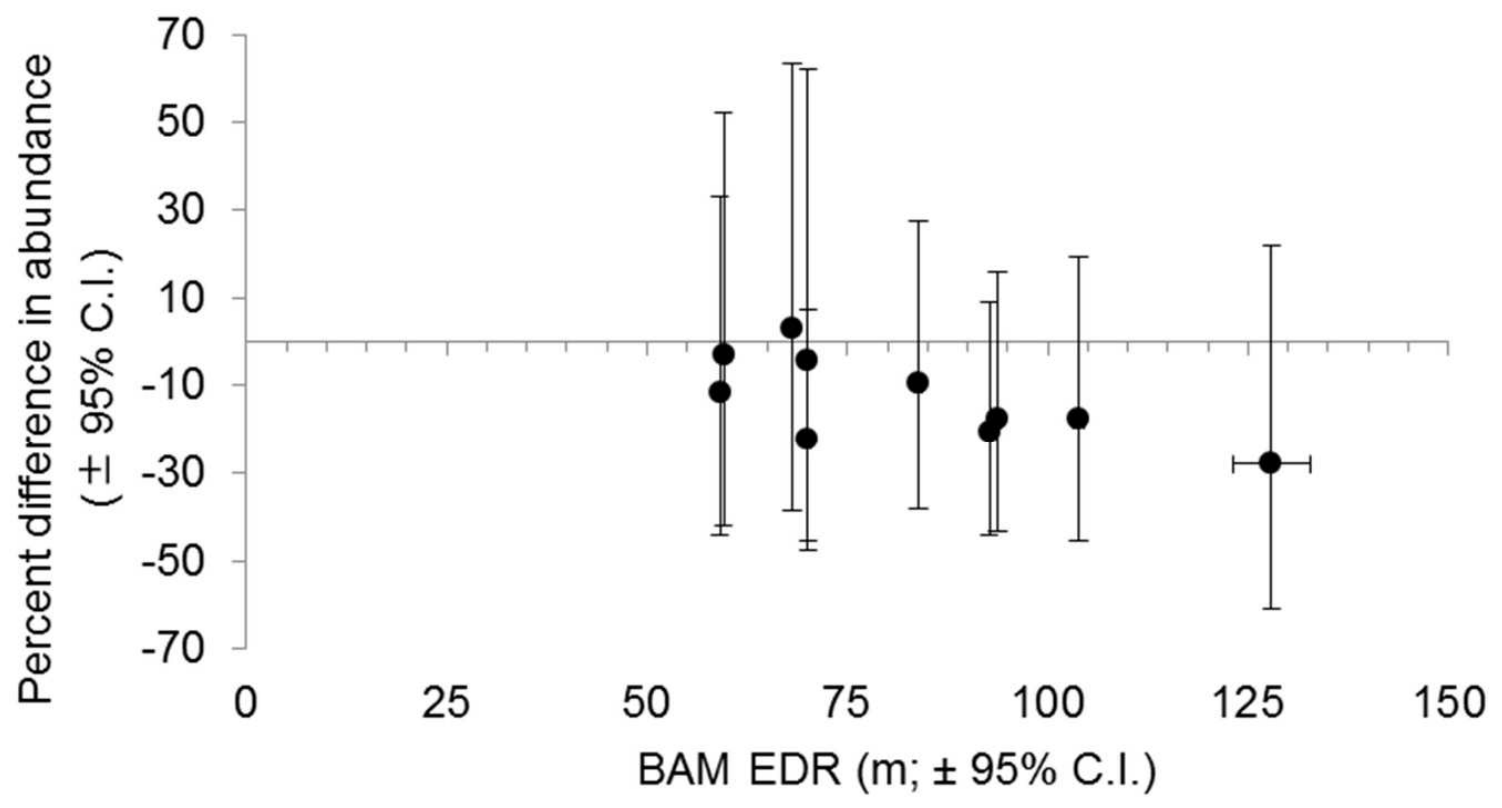

Figure A1.3. Relationship between BAM EDR ( $\pm 95 \%$ C.I. $)$ and percent difference $( \pm 95 \%$ C.I.) in relative abundance between on-road ARU BBS and forest-edge ARU BBS surveys (i.e. bias in detection). Each circle represents species-specific values. Bias values lower than 0 indicate higher counts for on-road ARU BBS surveys, while values higher than 0 indicate higher counts for forest-edge ARU BBS surveys. 


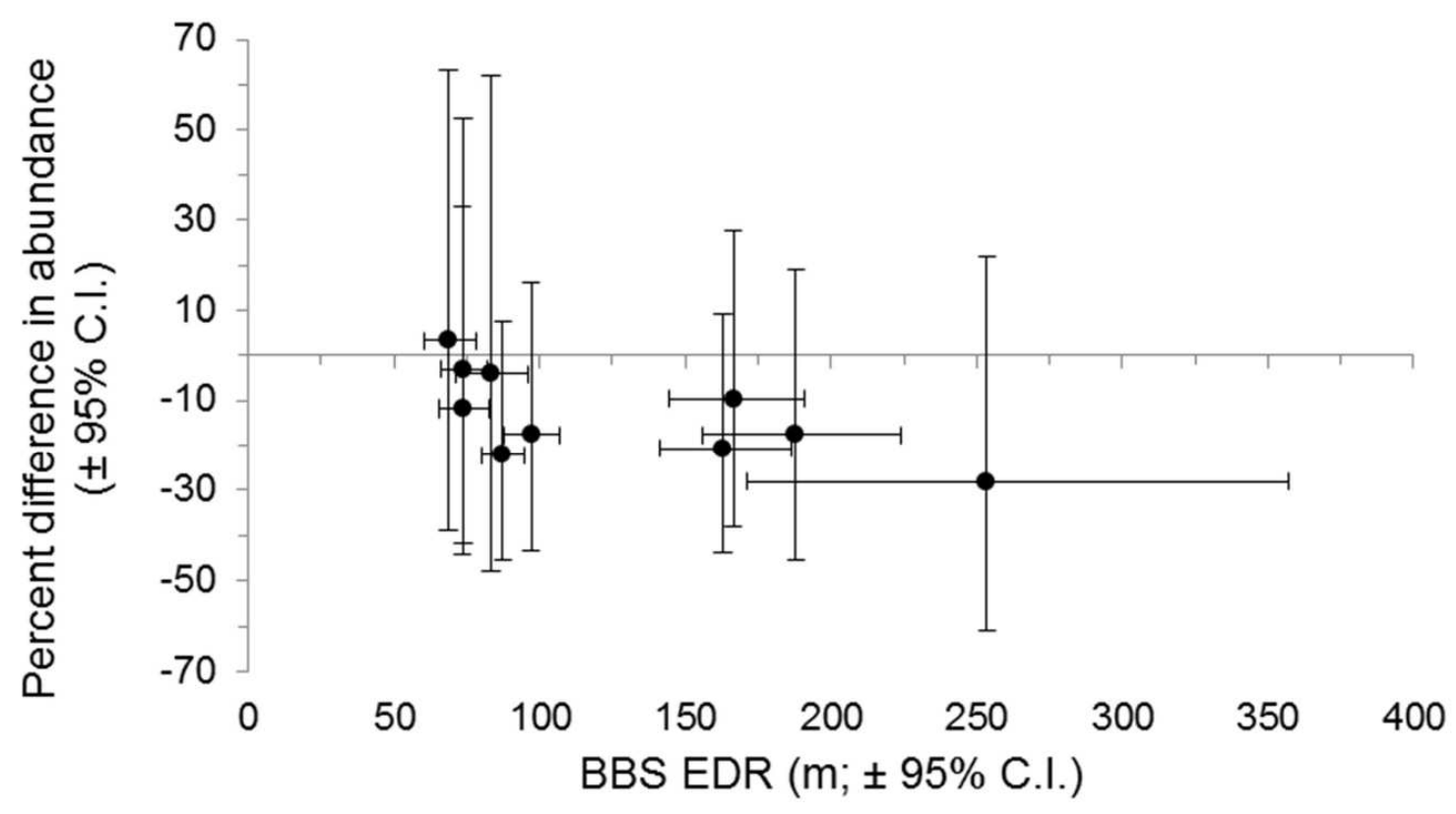

Figure A1.4. Relationship between BBS EDR ( $\pm 95 \%$ C.I. $)$ and percent difference $( \pm 95 \%$ C.I.) in relative abundance between on-road ARU BBS and forest-edge ARU BBS surveys (i.e. bias in detection). Each circle represents species-specific values. Bias values lower than 0 indicate higher counts for on-road ARU BBS surveys, while values higher than 0 indicate higher counts for forest-edge ARU BBS surveys. 
Appendix 2. Mean and total number of species counted.

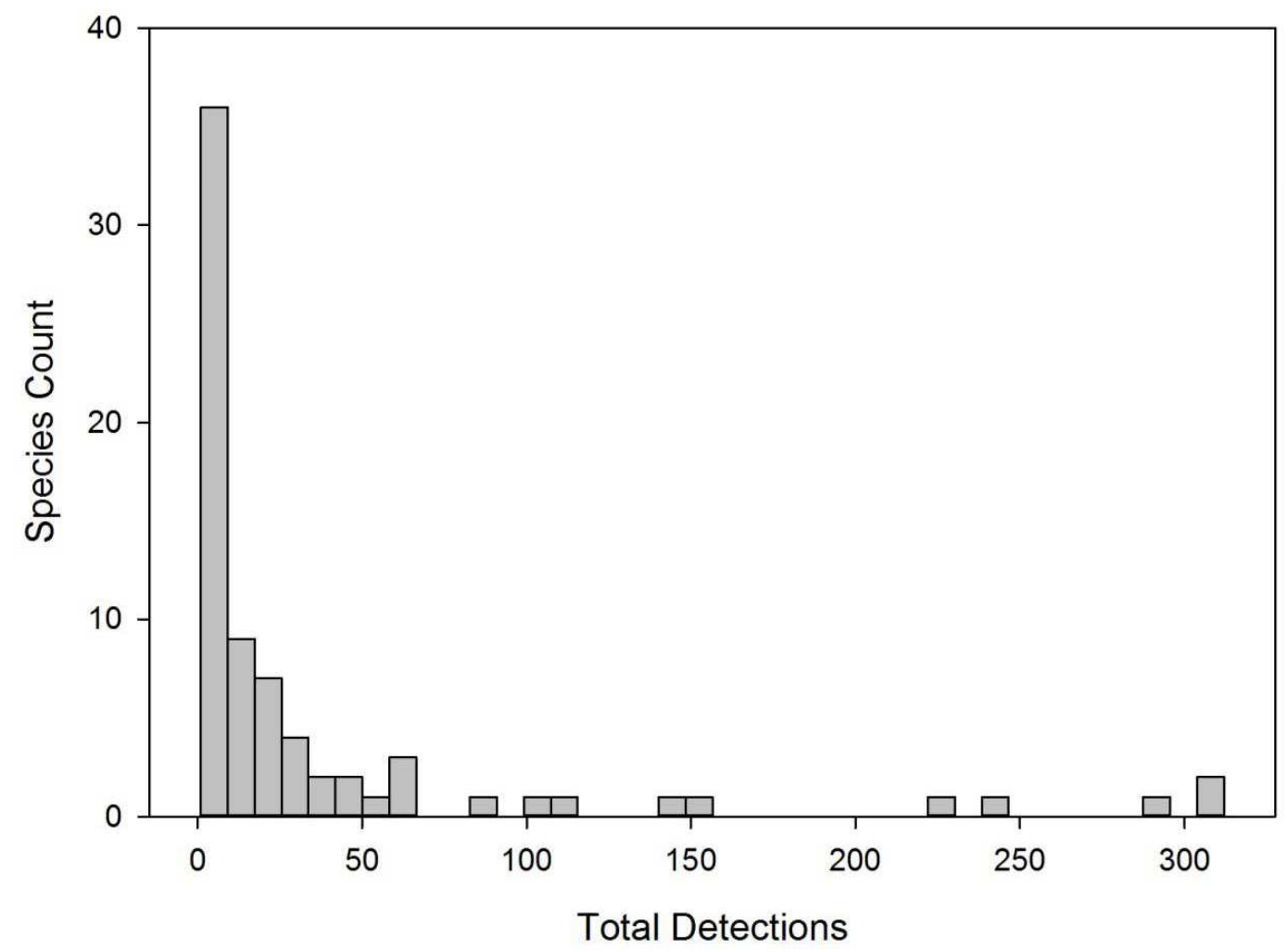

Figure A2.1. Distribution of the total number of individuals detected for each species irrespective of treatment and land cover type. A total of 351 individual birds from 76 species were detected in this study. 
Table A2.1. Total number of detection per survey type and land cover for the 76 species detected during this study.

\begin{tabular}{|c|c|c|c|c|c|c|c|c|c|}
\hline Species & Species Name & $\begin{array}{c}\text { Human } \\
\text { BBS }\end{array}$ & $\begin{array}{c}\text { On-road } \\
\text { ARU } \\
\text { BBS }\end{array}$ & $\begin{array}{c}\text { F-e ARU } \\
1 \text { week } \\
\text { earlier }\end{array}$ & $\begin{array}{c}\text { F-e } \\
\text { ARU } \\
\text { BBS }\end{array}$ & $\begin{array}{c}\text { F-e } \\
\text { ARU } \\
\text { Sunrise }\end{array}$ & $\begin{array}{c}\text { F-e } \\
\text { ARU } \\
\text { Sunset }\end{array}$ & $\begin{array}{c}\text { F-e ARU } \\
\text { Combined }\end{array}$ & Total \\
\hline Swainson's Thrush & (Catharus ustulatus) & 64 & 64 & 48 & 55 & 60 & 84 & 84 & 375 \\
\hline $\begin{array}{l}\text { White-throated } \\
\text { Sparrow }\end{array}$ & $\begin{array}{c}\text { (Zonotrichia } \\
\text { albicollis) }\end{array}$ & 76 & 78 & 53 & 61 & 92 & 8 & 92 & 368 \\
\hline Hermit Thrush & (Catharus guttatus) & 47 & 61 & 47 & 42 & 84 & 78 & 84 & 359 \\
\hline Chipping Sparrow & (Spizella passerine) & 82 & 77 & 39 & 59 & 70 & 1 & 70 & 328 \\
\hline American Robin & (Turdus migratorius) & 79 & 67 & 32 & 54 & 64 & 11 & 64 & 307 \\
\hline Dark-eyed Junco & (Junco hyemalis) & 36 & 32 & 26 & 32 & 58 & 4 & 58 & 188 \\
\hline $\begin{array}{l}\text { Yellow-rumped } \\
\text { Warbler }\end{array}$ & (Setophaga coronate) & 36 & 43 & 34 & 37 & 33 & 1 & 37 & 184 \\
\hline Tennessee Warbler & $\begin{array}{l}\text { (Oreothlypis } \\
\text { peregrine) }\end{array}$ & 42 & 34 & 20 & 32 & 21 & 3 & 32 & 152 \\
\hline Lincoln's Sparrow & (Melospiza lincolnii) & 26 & 25 & 18 & 23 & 35 & 1 & 35 & 128 \\
\hline Lesser Yellowlegs & (Tringa flavipes) & 26 & 29 & 12 & 20 & 9 & 13 & 20 & 109 \\
\hline Palm Warbler & $\begin{array}{l}\text { (Setophaga } \\
\text { palmarum) }\end{array}$ & 32 & 26 & 10 & 16 & 11 & 0 & 16 & 95 \\
\hline Alder Flycatcher & (Empidonax alnorum) & 28 & 18 & 10 & 13 & 22 & 2 & 22 & 93 \\
\hline Wilson's Snipe & (Gallinago delicate) & 22 & 26 & 8 & 13 & 6 & 7 & 13 & 82 \\
\hline Gray Jay & $\begin{array}{l}\text { (Perisoreus } \\
\text { Canadensis) }\end{array}$ & 18 & 21 & 9 & 15 & 4 & 2 & 15 & 69 \\
\hline $\begin{array}{l}\text { Orange-crowned } \\
\text { Warbler }\end{array}$ & (Oreothlypis celata) & 15 & 13 & 9 & 10 & 17 & 0 & 17 & 64 \\
\hline $\begin{array}{l}\text { White-winged } \\
\text { Crossbill }\end{array}$ & (Loxia leucoptera) & 47 & 3 & 0 & 3 & 4 & 0 & 4 & 57 \\
\hline Common Raven & (Corvus corax) & 14 & 13 & 14 & 10 & 4 & 0 & 14 & 55 \\
\hline Swamp Sparrow & $\begin{array}{l}\text { (Melospiza } \\
\text { georgiana) }\end{array}$ & 10 & 9 & 8 & 10 & 12 & 0 & 12 & 49 \\
\hline $\begin{array}{l}\text { Ruby-crowned } \\
\text { Kinglet }\end{array}$ & (Regulus calendula) & 14 & 11 & 8 & 7 & 5 & 0 & 8 & 45 \\
\hline $\begin{array}{l}\text { Common } \\
\text { Nighthawk }\end{array}$ & (Chordeiles minor) & 1 & 0 & 0 & 0 & 0 & 42 & 42 & 43 \\
\hline
\end{tabular}




\begin{tabular}{|c|c|c|c|c|c|c|c|c|c|}
\hline Least Flycatcher & (Empidonax minimus) & 12 & 9 & 7 & 7 & 8 & 0 & 8 & 43 \\
\hline $\begin{array}{l}\text { Red-winged } \\
\text { Blackbird }\end{array}$ & (Agelaius phoeniceus) & 13 & 12 & 5 & 8 & 3 & 0 & 8 & 41 \\
\hline $\begin{array}{l}\text { White-crowned } \\
\text { Sparrow }\end{array}$ & $\begin{array}{l}\text { (Zonotrichia } \\
\text { leucophrys) }\end{array}$ & 11 & 8 & 4 & 8 & 7 & 2 & 8 & 40 \\
\hline Red-eyed Vireo & (Vireo olivaceus) & 5 & 7 & 5 & 5 & 7 & 0 & 7 & 29 \\
\hline Blue-headed Vireo & (Vireo solitaries) & 5 & 5 & 3 & 7 & 4 & 1 & 7 & 25 \\
\hline $\begin{array}{c}\text { Northern } \\
\text { Waterthrush }\end{array}$ & $\begin{array}{c}\text { (Parkesia } \\
\text { noveboracensis) }\end{array}$ & 4 & 8 & 8 & 4 & 1 & 0 & 8 & 25 \\
\hline Solitary Sandpiper & (Tringa solitaria) & 6 & 7 & 4 & 5 & 3 & 0 & 5 & 25 \\
\hline Ruffed Grouse & (Bonasa umbellus) & 0 & 7 & 1 & 7 & 7 & 1 & 7 & 23 \\
\hline Sandhill Crane & (Antigone canadensis) & 4 & 5 & 6 & 2 & 1 & 5 & 6 & 23 \\
\hline Yellow Warbler & (Setophaga petechial) & 13 & 3 & 4 & 2 & 1 & 0 & 4 & 23 \\
\hline Pine Siskin & (Spinus pinus) & 2 & 8 & 4 & 5 & 3 & 0 & 5 & 22 \\
\hline Common Loon & (Gavia immer) & 7 & 6 & 1 & 5 & 0 & 1 & 5 & 20 \\
\hline Western Tanager & (Piranga ludoviciana) & 4 & 4 & 8 & 1 & 0 & 0 & 8 & 17 \\
\hline $\begin{array}{l}\text { Common } \\
\text { Yellowthroat }\end{array}$ & (Geothlypis trichas) & 4 & 3 & 2 & 3 & 2 & 1 & 3 & 15 \\
\hline $\begin{array}{l}\text { Yellow-bellied } \\
\text { Sapsucker }\end{array}$ & (Sphyrapicus varius) & 4 & 4 & 0 & 4 & 3 & 0 & 4 & 15 \\
\hline Spotted Sandpiper & (Actitis macularius) & 2 & 6 & 1 & 3 & 1 & 1 & 3 & 14 \\
\hline American Crow & $\begin{array}{c}\text { (Corvus } \\
\text { brachyrhynchos) }\end{array}$ & 1 & 4 & 0 & 6 & 2 & 0 & 6 & 13 \\
\hline American Redstart & (Setophaga ruticilla) & 4 & 3 & 4 & 1 & 1 & 0 & 4 & 13 \\
\hline $\begin{array}{l}\text { Clay-colored } \\
\text { Sparrow }\end{array}$ & (Spizella pallida) & 5 & 4 & 1 & 3 & 0 & 0 & 3 & 13 \\
\hline Cape May Warbler & (Setophaga tigrina) & 3 & 3 & 5 & 2 & 0 & 0 & 5 & 13 \\
\hline $\begin{array}{l}\text { Western Wood- } \\
\text { Pewee }\end{array}$ & (Contopus sordidulus) & 4 & 3 & 1 & 4 & 1 & 0 & 4 & 13 \\
\hline Lesser Scaup & (Aythya affinis) & 12 & 0 & 0 & 0 & 0 & 0 & 0 & 12 \\
\hline $\begin{array}{l}\text { Olive-sided } \\
\text { Flycatcher }\end{array}$ & (Contopus cooperi) & 4 & 3 & 0 & 1 & 2 & 2 & 2 & 10 \\
\hline Sora & (Porzana carolina) & 2 & 2 & 2 & 0 & 3 & 1 & 3 & 10 \\
\hline
\end{tabular}




\begin{tabular}{|c|c|c|c|c|c|c|c|c|c|}
\hline $\begin{array}{l}\text { Yellow-bellied } \\
\text { Flycatcher }\end{array}$ & $\begin{array}{l}\text { (Empidonax } \\
\text { flaviventris) }\end{array}$ & 2 & 1 & 1 & 2 & 2 & 0 & 2 & 8 \\
\hline $\begin{array}{l}\text { Bay-breasted } \\
\text { Warbler }\end{array}$ & (Setophaga castanea) & 3 & 1 & 1 & 2 & 0 & 0 & 2 & 7 \\
\hline Boreal Chickadee & (Poecile hudsonicus) & 4 & 2 & 0 & 1 & 0 & 0 & 1 & 7 \\
\hline Bonaparte's Gull & $\begin{array}{c}\text { (Chroicocephalus } \\
\text { Philadelphia) }\end{array}$ & 1 & 2 & 1 & 1 & 1 & 0 & 1 & 6 \\
\hline Mew Gull & (Larus canus) & 0 & 2 & 2 & 0 & 2 & 0 & 2 & 6 \\
\hline Fox Sparrow & (Passerella iliaca) & 1 & 2 & 0 & 1 & 1 & 0 & 1 & 5 \\
\hline Hairy Woodpecker & (Picoides villosus) & 1 & 2 & 0 & 2 & 0 & 0 & 2 & 5 \\
\hline Northern Flicker & (Colaptes auratus) & 3 & 1 & 1 & 0 & 0 & 0 & 1 & 5 \\
\hline $\begin{array}{l}\text { Black-and-white } \\
\text { Warbler }\end{array}$ & (Mniotilta varia) & 0 & 2 & 1 & 0 & 1 & 0 & 1 & 4 \\
\hline Canada Goose & (Branta Canadensis) & 1 & 1 & 1 & 1 & 0 & 0 & 1 & 4 \\
\hline Mallard & (Anas platyrhynchos) & 0 & 2 & 0 & 2 & 0 & 0 & 2 & 4 \\
\hline Magnolia Warbler & (Setophaga magnolia) & 1 & 1 & 0 & 1 & 1 & 0 & 1 & 4 \\
\hline Ovenbird & (Seiurus aurocapilla) & 1 & 0 & 0 & 1 & 2 & 0 & 2 & 4 \\
\hline Red-necked Grebe & (Podiceps grisegena) & 0 & 0 & 0 & 0 & 3 & 1 & 3 & 4 \\
\hline Tree Swallow & (Tachycineta bicolor) & 0 & 0 & 1 & 0 & 3 & 0 & 3 & 4 \\
\hline American Kestrel & (Falco sparverius) & 1 & 2 & 0 & 0 & 0 & 0 & 4 & 3 \\
\hline Bald Eagle & $\begin{array}{c}\text { (Haliaeetus } \\
\text { leucocephalus) }\end{array}$ & 2 & 1 & 0 & 0 & 0 & 0 & 0 & 3 \\
\hline Pacific Loon & (Gavia pacifica) & 0 & 1 & 0 & 1 & 0 & 1 & 1 & 3 \\
\hline $\begin{array}{c}\text { Pileated } \\
\text { Woodpecker }\end{array}$ & (Dryocopus pileatus) & 0 & 2 & 0 & 1 & 0 & 0 & 1 & 3 \\
\hline Wilson's Warbler & (Cardellina pusilla) & 0 & 1 & 2 & 0 & 0 & 0 & 2 & 3 \\
\hline American Coot & (Fulica Americana) & 0 & 0 & 0 & 0 & 2 & 0 & 2 & 2 \\
\hline Barn Swallow & (Hirundo rustica) & 1 & 1 & 0 & 0 & 0 & 0 & 0 & 2 \\
\hline California Gull & (Larus californicus) & 0 & 0 & 0 & 0 & 2 & 0 & 0 & 2 \\
\hline
\end{tabular}




\begin{tabular}{|c|c|c|c|c|c|c|c|c|c|}
\hline Great Horned Owl & (Bubo virginianus) & 0 & 0 & 0 & 0 & 1 & 1 & 1 & 2 \\
\hline Le Conte's Sprrow & $\begin{array}{c}\text { (Ammodramus } \\
\text { leconteii) }\end{array}$ & 0 & 0 & 1 & 0 & 0 & 1 & 1 & 2 \\
\hline Rusty Blackbird & (Euphagus carolinus) & 1 & 1 & 0 & 0 & 0 & 0 & 0 & 2 \\
\hline American Wigeon & (Anas Americana) & 0 & 0 & 1 & 0 & 0 & 0 & 1 & 1 \\
\hline $\begin{array}{l}\text { Black-billed } \\
\text { Magpie }\end{array}$ & (Pica hudsonia) & 0 & 0 & 1 & 0 & 0 & 0 & 1 & 1 \\
\hline $\begin{array}{l}\text { Black-backed } \\
\text { Woodpecker }\end{array}$ & (Picoides arcticus) & 1 & 0 & 0 & 0 & 0 & 0 & 0 & 1 \\
\hline $\begin{array}{l}\text { Black-capped } \\
\text { Chickadee }\end{array}$ & (Poecile atricapillus) & 0 & 0 & 0 & 0 & 1 & 0 & 1 & 1 \\
\hline Common Grackle & (Quiscalus quiscula) & 1 & 0 & 0 & 0 & 0 & 0 & 0 & 1 \\
\hline Herring Gull & (Larus argentatus) & 1 & 0 & 0 & 0 & 0 & 0 & 0 & 1 \\
\hline Horned Grebe & (Podiceps auritus) & 1 & 0 & 0 & 0 & 0 & 0 & 0 & 1 \\
\hline $\begin{array}{l}\text { Rose-breasted } \\
\text { Grosbeak }\end{array}$ & $\begin{array}{l}\text { (Pheucticus } \\
\text { ludovicianus) }\end{array}$ & 0 & 0 & 0 & 0 & 1 & 0 & 1 & 1 \\
\hline
\end{tabular}


Appendix 3. Figures showing difference in species richness and total number of birds between forest-edge autonomous recording unit (ARU) North American Breeding Bird Survey (BBS) and sunrise surveys at each BBS stop from three routes in the Northwest Territories, Canada.

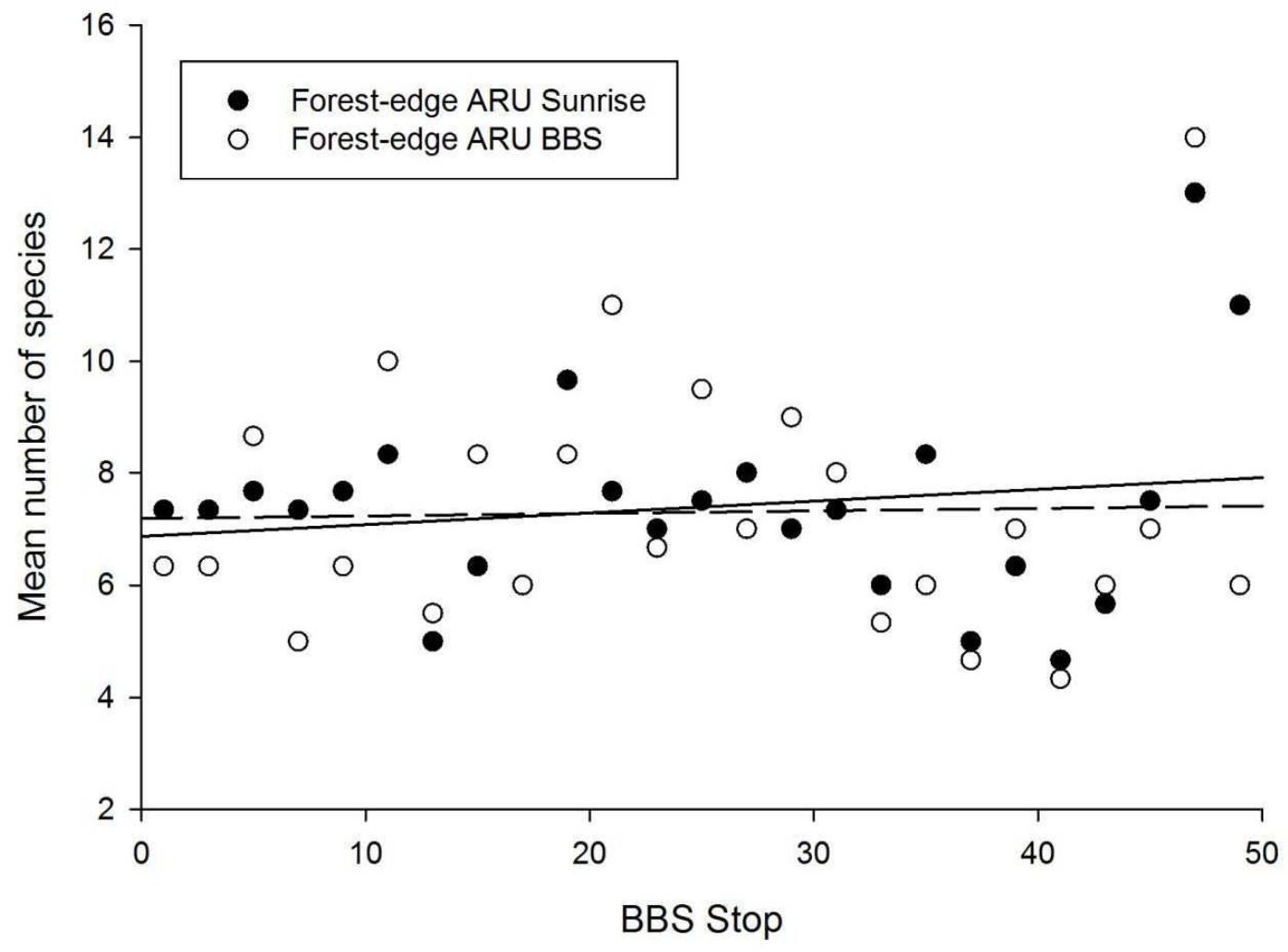

Figure A3.1. Mean number of species detected at each BBS stop from forest-edge ARU-based surveys conducted in 2015 during traditional BBS time and sunrise on three routes conducted in the Northwest Territories, Canada. Solid and broken lines indicate Forest-edge ARU Sunrise and Forest-edge ARU BBS, respectively. 


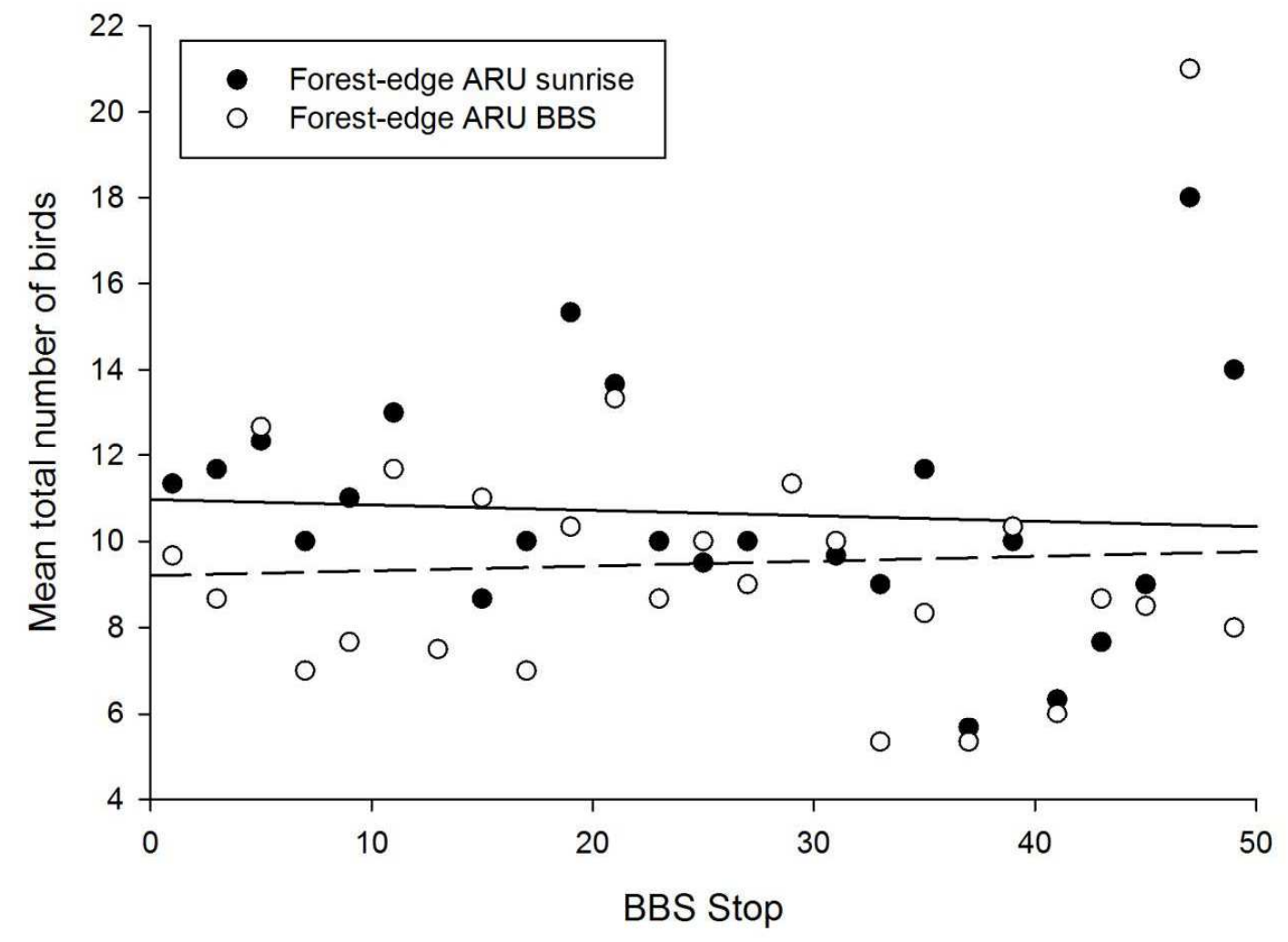

Figure A3.2. Mean total number of birds detected at each BBS stop from forest-edge ARUbased surveys conducted in 2015 during traditional BBS time and sunrise on three routes conducted in the Northwest Territories, Canada. Solid and broken lines indicate Forest-edge ARU Sunrise and Forest-edge ARU BBS, respectively. 